GRØNLANDS GEOLOGISKE UNDERSØGELSE BulletiN No. 43

\title{
THE OCCURRENCE OF NICKEL- ARSENIDES AND NICKEL-ANTIMONIDE AT IGDLÚNGUAQ, IN THE ILÍMAUSSAQ ALKALINE MASSIF, SOUTH GREENLAND
}

B Y

OEN ING SOEN AND HENNING SØRENSEN

WITH 13 FIGURES IN THE TEXT AND 4 PLATES

Reprinted from

Meddelelser om Grenland Bd. 172, Nr. 1

K ØBENHAVN

BIANCOLUNOS BOGTRYKKERI A/S

1964 


\section{LIST OF CONTENTS}

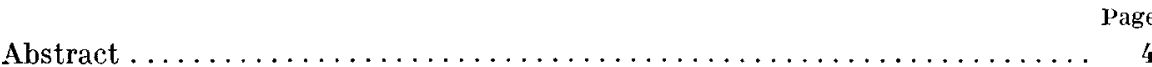

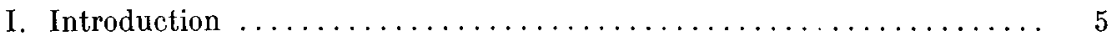

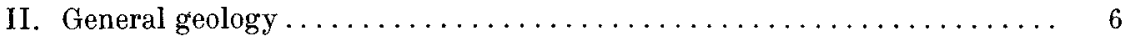

III. Ore minerals in the rocks of the Ilimaussaq massif $\ldots \ldots \ldots \ldots \ldots \ldots \quad 8$

IV. The occurrence of niccolite and other ore minerals at Igdlunguaq..... 10

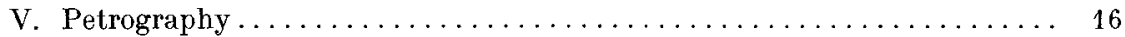

The naujaite............................... 16

The contact zone between the naujaite and the acmite-arfvedsonite vein $\mathbf{1 6}$

The acmite-arfvedsonite vein $\ldots \ldots \ldots \ldots \ldots \ldots \ldots \ldots \ldots \ldots \ldots \ldots$

VI. Diagnostic properties of the ore minerals . . . . . . . . . . . . . . 19

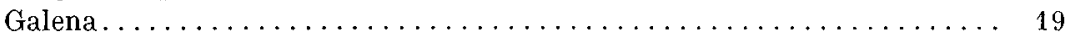

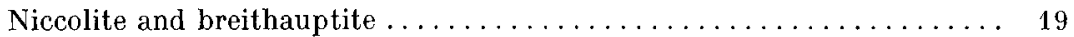

Maucherite ............................. 19

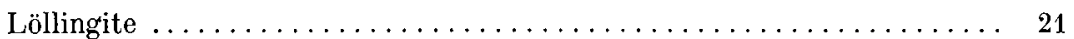

Skutterudite. . . . . . . . . . . . . . . . . . . . . . . . 21

Gudmundite .................................. 22

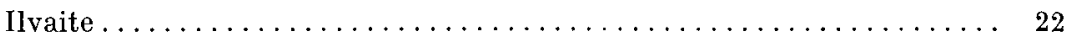

VII. Textural relations of the ore minerals . . . . . . . . . . . . . 23

Relations between the ore minerals and the other rock components ... . 23

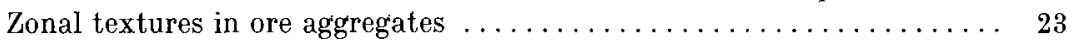

Skutterudite-niccolite relationships ................... 24

Skutterudite-maucherite and niccolite-maucherite relationships; cell or pseudo-cell textures ............................ 26

Skutterudite-breithauptite and niccolite-breithauptite myrmekites.... 28

Breithauptite rims and crack-fillings with columnar textures ........ 29

Myrmekitic and bladed intergrowths of maucherite and breithauptite ... 30

Bladed intergrowths of maucherite and lölingite ............. 35

Network or cell textures of breithauptite and löllingite .......... 36

Breithauptite-maucherite-gudmundite relationships; bladed intergrowths of breithauptite and gudmundite $\ldots \ldots \ldots \ldots \ldots \ldots \ldots \ldots \ldots \ldots \ldots$

The relations between galena and the other ore minerals $\ldots \ldots \ldots \ldots . \ldots 37$

VIII. Discussion and conclusions ......................... 38

1. On the occurrence of nickel, cobalt and arsenic in agpaitic rocks.... 38

2. On the occurrence of ore minerals in late veins associated with alkaline rocks .................................... 39

3. On the origin of the acmite-arfvedsonite veins in Ilimaussaq . . . . 40

4. Possible interpretations of the ore textures $\ldots \ldots \ldots \ldots \ldots \ldots \ldots 42$

5. On the origin of the ore minerals ................ 47

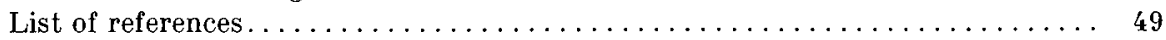

Plates ........................................... 51 


\begin{abstract}
.
Ore minerals are rare in the alkaline rocks of the Ilimaussaq massif in SW. Greenland. At the locality of Igdlunguaq on the North coast of the Tunugdliarfik fjord accessory amounts of $\mathrm{Ni}$-arsenides and $\mathrm{Ni}$-antimonide have been found in natrolitized naujaite adjacent to an acmite-arfvedsonite vein. The latter is later than the naujaite but earlier than or contemporaneous with the neighbouring lujavrites. A brief description of the field occurrence and petrography of the ore-bearing naujaite and the acmitite-arfvedsonite vein is given.

The ore minerals in the naujaite occur in very small and fine-grained aggregates, which consist of galena, skutterudite, niccolite, breithauptite, maucherite, löllingite and gudmundite. Diablastic intergrowths are common. Niccolite-maucherite network or cell textures, skutterudite-breithauptite and niccolite-breithauptite myrmekites, maucherite-breithauptite myrmekites and breithauptite-maucherite myrmekites and bladed intergrowths, breithauptite-löllingite network or cell textures, maucherite-löllingite bladed intergrowths, breithauptite-gudmundite bladed intergrowths, as well as certain zonal and other textures are described and their significance discussed.

It is concluded that the observed assemblages of ore minerals and their characteristic textures have resulted from the modification at temperatures around $400^{\circ} \mathrm{C}$ of earlier formed ore minerals, which are thought to have included galena, skutterudite, niccolite and breithauptite. The acmite-arfvedsonite vein is believed to have been formed by replacement of the naujaite along a fracture or fault plane. It is thought that the modifications of the earlier ore minerals in the naujaite are genetically related, in both time and space, with the formation of the acmite-arfvedsonite vein which is believed to be connected with the emplacement of the neighbouring lujavrites. It is suggested that fracturing of rocks, recementation of cracks and fractures, and the circulation of pneumatolytic or hydrothermal fluids having differential dissolving power for $\mathrm{As}, \mathrm{Sb}, \mathrm{S}$ and other components in the system of ore minerals, may have caused significant changes in the partial vapour pressures of these components. Such changes in partial vapour pressures of $\mathrm{As}, \mathrm{Sb}$ and $\mathrm{S}$ are regarded as the main factors controlling the mineralogical and textural modifications of the ore minerals. The zeolites and other low-temperature minerals in the acmitearfvedsonite vein were formed at a late stage of the vein formation, when temperature had already declined appreciably.

With regard to the origin of the ore minerals no conclusive arguments can be presented. Field evidence seems to favour the possibility that the components of the ore minerals have been completely or partly introduced into the naujaite as a result of hydrothermal action connected with the emplacement of the lujavrites and with the associated acmite-arfvedsonite veins. However, the possibility cannot be excluded that the ore minerals were present in the naujaite as primary magmatic minerals, which were subsequently modified during the emplacement of the lujavrite.
\end{abstract}




\section{INTRODUCTION}

In the summer of 1957 one of the authors (H.S.) found small spots of niccolite and other ore minerals in the Ilímaussaq alkaline massif, South Greenland. These ore minerals have been found only at one locality, Igdlúnguaq on the north coast of the Tunugdliarfik fjord. They are so scarce that no more traces of ore minerals have been found during further visits to the locality in 1960 (O.I.S.) and in 1962 (H.S.).

The niccolite and associated ore minerals present so intricate structural and textural relations that we feel justified in presenting a description of these minerals notwithstanding their extreme rarity.

Oen Ing Soen has undertaken the ore microscopical examination of the material, while working for "Grønlands geologiske Undersøgelse " in Copenhagen; H. Sørensen the field work and petrographic examinations. The discussion of the paragenesis and origin of the ore minerals is a co-operative effort.

We are indebted to Mrs. M. Danø, Mr. Ib Sørensen, Mr. Chr. Halkier, Mrs. R. Larsen and Miss G. Hansen, all of the Mineralogical Museum of the University of Copenhagen, respectively for X-ray examination of some minerals, for spectrographic examinations, for the microphotographs, for drawing the diagrams and for typing the manuscript. Miss Else Breval assisted in the field. Mr. J. Watterson kindly corrected the English of the manuscript.

October 1962.

Oen Ing Soen

Geologisch Instituut der Universiteit van Amsterdam.
Henning Sørensen

Mineralogisk-geologisk Museum. The University of Copenhagen. 


\section{GENERAL GEOLOGY}

The Ilimaussaq alkaline massif is situated on the Tunugdliarfik fjord a few kilometres to the east of Narssaq. The massif was described in great detail by Ussing (1912). A summary of the geology of the massif has been given by SøRENSEN (1958). A new geological map of the Ilímaussaq massif and a description of the map will be published by FerGuson (1964).

The massif is composed of an older unbanded series of common rock types (augite syenite, essexite, nordmarkite and alkali granite) and of a younger banded series of uncommon per-alkaline rock types, foyaite and alkali granite. The per-alkaline rocks comprise sodalite foyaite, naujaite, lujavrite and kakortokite (Ussivg, op.cit.). These per-alkaline rocks form a peculiar sub-group of the nepheline syenites which has been termed agpaitic by Ussing (cf. Sørensen, 1960).

The agpaitic rocks are very probably derived from an augite syenitic magma enriched in volatiles (Sørensen, 1958 and Ferguson, 1964). They were formed in two stages. In the first stage sodalite foyaite and naujaite crystallized in the upper part of the magma chamber while the kakortokites were formed in the lower part of the chamber. The lujavrite intruded these rocks during the second stage and according to Ferguson (op.cit.) it occupies an intermediate position between naujaite and kakortokite. Veins of lujavrite cut the naujaite and fragments of the latter rock are enclosed in the larger masses of lujavrite.

Only the naujaite and the lujavrite will be considered in the present paper.

The naujaite is a very coarse-grained nepheline syenite characterized by peculiar poikilitic textures. Small crystals of sodalite are enclosed in large anhedra of microcline, eudialyte, ægirine and arfvedsonite. The sodalite crystals are often so closely spaced that the above-mentioned minerals are reduced to a thin interstitial network. Nepheline occurs as stout prisms. The naujaite may display an irregular banding. Accessories are ænigmatite, rinkite, sphalerite and others; secondary minerals are analcime and natrolite.

The lujavrite is a fine-grained melanocratic rock which often shows a pronounced lamination and even schistosity. The mafics make up 
$30-50 \%$ of the rock. Two varieties have been distinguished by Ussing (op.cit.), a green one rich in ægirine and a black one rich in arfvedsonite. The light coloured minerals are microcline and/or albite, nepheline and sometimes sodalite. Small crystals of eudialyte make up $2-10 \%$ of the lujavrite. The acicular grains of arfvedsonite and ægirine, the laths of feldspar, the nepheline prisms and the eudialyte plates lie within the planes of lamination. Accessories are sphalerite, schizolite, steenstrupine, monazite and others; secondary minerals are analcime, natrolite, ussingite and katapleite.

The naujaite contains zoned pegmatites rich in eudialyte and other more irregular pegmatitic masses.

The naujaite and its pegmatites are cut by several types of late veins: green veins composed of felted ægirine, brown and black veins rich in acmite and arfvedsonite, and light coloured veins composed of one or more of the minerals albite, analcime, natrolite, sodalite and ussingite. These late veins are often rich in steenstrupine, britholite, sphalerite, schizolite, lepidolite, epistolite, pyrochlore and other rare minerals. Eudialyte is generally lacking. The late veins have never been observed in the lujavrite but they may be contiguous with lujavrite veins in fractures in the naujaite. According to Sørensen (1962) the green veins are slightly earlier than the lujavrite, marking the opening of the second phase of agpaitic magma activity in Ilímaussaq. The brown and black veins are contemporaneous with or slightly earlier than the lujavrite. The light coloured veins are generally younger than the lujavrite being connected with the latest stages of crystallization of the latter rock. 


\section{ORE MINERALS IN THE ROCKS OF THE ILIMAUSSAQ MASSIF}

Ore minerals are common in the unbanded rocks of the complex. Thus iron-oxides, in part titaniferous, are common in the essexite and augite syenite, while pyrite and chalcopyrite have been observed along fractures in the essexite.

The agpaitic rocks are poor in ore minerals. Iron-oxides are practically absent and this in spite of the high iron content of some of the rocks, for instance about $10 \% \mathrm{FeO}+\mathrm{Fe}_{2} \mathrm{O}_{3}$ in the lujavrite. The iron is, however, contained in silicate minerals.

Rust coloured spots in the naujaite are quite common, but have so far been regarded as weathered silicate minerals. However, in the summer of 1961 blasting was undertaken in the naujaite at the head of Kangerdluarssuk in order to obtain unweathered specimens. At this locality it was seen that the rust coloured spots are caused by the alteration of small aggregates of sulphides up to half a centimetre across. The aggregates of sulphides are composed mainly of pyrrhotite but small amounts of stannite and polybasite-pearceite occur in association with the pyrrhotite. The stannite shows a finely developed cross-hatched microcline-like twinning, which according to Raм⿰он (1960, p. 510-512) indicates that the mineral originally crystallized in its high-temperature cubic form.

Traces of löllingite have been reported by FLIN K $(1898$, p. 245) from Naujakasik.

Small flakes of molybdenite have occasionally been observed in the naujaite and in the naujaite pegmatites.

The kakortokites locally contain small amounts of pyrrhotite and galena, which appears from an examination by John FerGuson and one of the writers (O.I.S.).

Small grains of galena, less than one millimetre across, occur in some of the late analcime-rich veins. These grains are associated with steenstrupine and pseudomorphs after eudialyte (composed of katapleite, pyrochlore, analcime and other minerals).

Sphalerite is the only common ore mineral in the agpaitic rocks. It is a common accessory mineral in the lujavrites and also occurs in 
the naujaite, naujaite pegmatites and the late veins. The pegmatites and the albite-rich late veins contain yellow or light brown grains of sphalerite which are several centimetres across. A sample of sphalerite from the late albititic vein at Tugtup agtakôrfia contains $5.40 \mathrm{~mol}$ per cent $\mathrm{FeS}$ which corresponds to a temperature of formation of $170^{\circ} \mathrm{C}$ (the FeS-ZnS thermometer, Kullerud, 1953, p. 129). However, it should be pointed out that this sphalerite has not been formed in equilibrium with other iron-bearing minerals; consequently, the temperature of formation indicated by this method should be regarded with some reservation. In some cases, the sphalerite is partially altered into a fine-grained aggregate of sheaf-like hemimorphite. 


\section{THE OCCURRENCE OF NICCOLITE AND OTHER ORE MINERALS AT IGDLÚNGUAQ}

The small point of Igdlúnguaq on the north coast of the Tunugdliarfik Fjord is situated in the breccia zone of Ussing $(1912$, p. 36), that is, a zone composed of lujavrite with inclusions of naujaite (cf. fig. 3). Some naujaite inclusions are rotated and tilted and are cut by lujavrite veins. The breccia zone may therefore be regarded as an intrusion breccia on the border between the upper naujaite and the lower lujavrite (cf. Sørensen, 1962).

The naujaite of this locality is rather light coloured and contains some analcime and natrolite. The poikilitic texture is generally well developed. A banding consisting of an alternation of dark æoirine-rich bands, reddish-coloured eudialyte-rich bands and light coloured microcline-rich bands is locally developed.

The lujavrite is of the black, arfvedsonite-rich type and contains inclusions of naujaite in all stages of digestion. Lujavrite in contact with naujaite, as for instance where thin lujavrite veins cut the naujaite, is enriched in analcime and arfvedsonite and may contain poikilitic grains of steenstrupine.

The marginal zones of the large inclusions of naujaite are often strongly analcitized. Eudialyte has disappeared from these zones, and steenstrupine occurs instead. The analcime-rich parts of the naujaite inclusions have in some cases been mobilized, forming analcime-steenstrupine veins which cut the enclosing (and younger) lujavrite.

The naujaite is traversed by a number of thin veins (cf. fig. 2 and Sørenser, 1962). These veins do not cut the lujavrite but are occasionally contiguous with lujavrite veins occupying the same fissures in the naujaite. Three types of veins may be distinguished:

1. Green veins composed of felt-like ægirine, microcline, steenstrupine and a few other minerals. These veins often occur in zones of deformation in the naujaite. The veins are in some cases partially replaced by lujavrite and they are thus earlier than that rock.

2. Brown or black veins rich in acmite and/or arfvedsonite. They may have coarse-grained patches rich in analcime, natrolite, sodalite, 


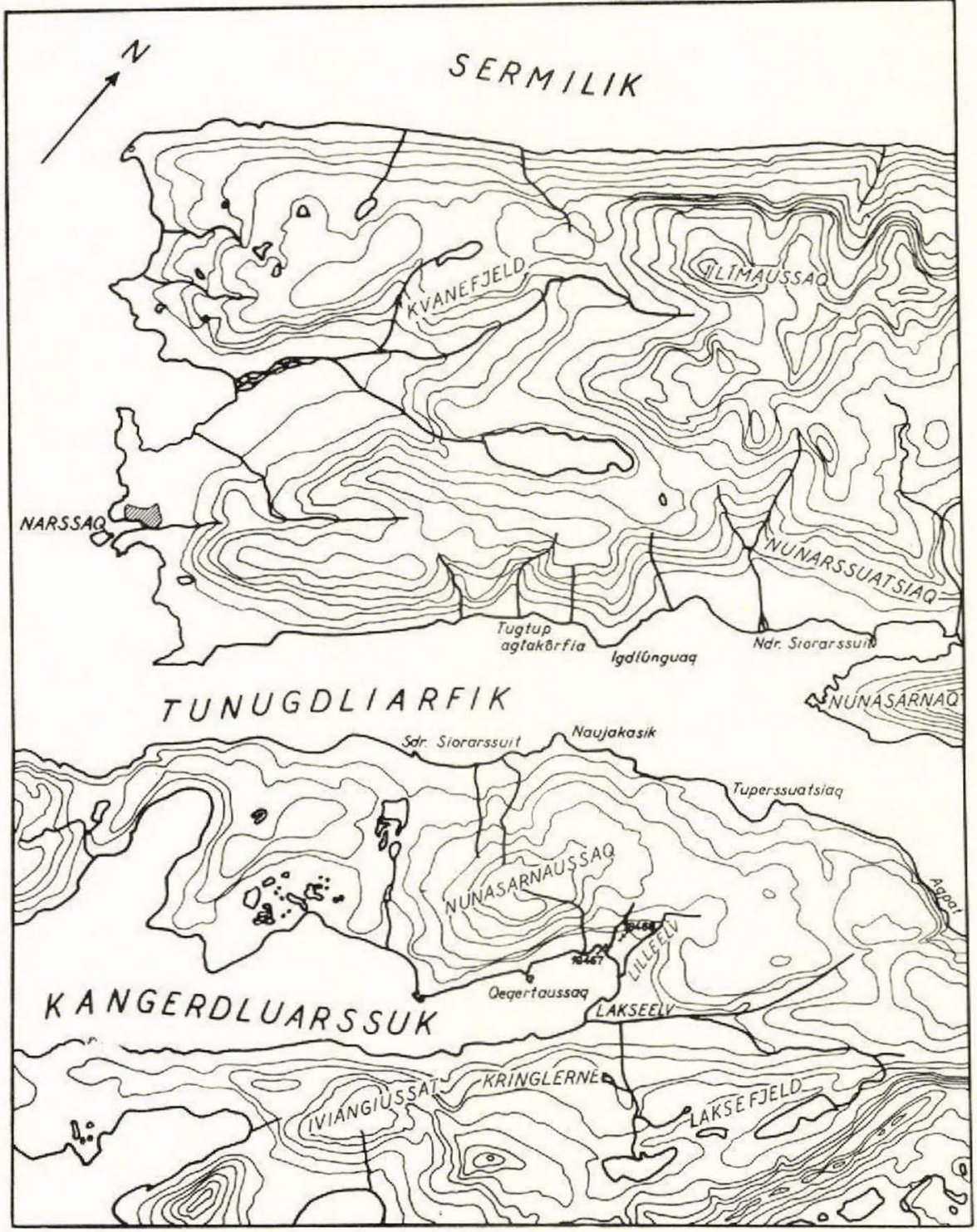

Fig. 1. Map showing the localities mentioned in the text. Scale $1: 143.000$; equidistances $100 \mathrm{~m}$. The map is based on a preliminary 1:50.000 map kindly supplied by the Geodetic Institute, Copenhagen (Copyright the Geodetic Institute). Geological maps are to be found in Ussivg (1912), Sorensen (1958) and Ferguson (1964).

steenstrupine and a number of other minerals. The veins are sometimes contiguous with lujavrite veins. Naujaite bands cut by these veins may be slightly displaced and slickensides are sometimes developed in the border zones of the veins. The acmite and arfvedsonite of these veins 


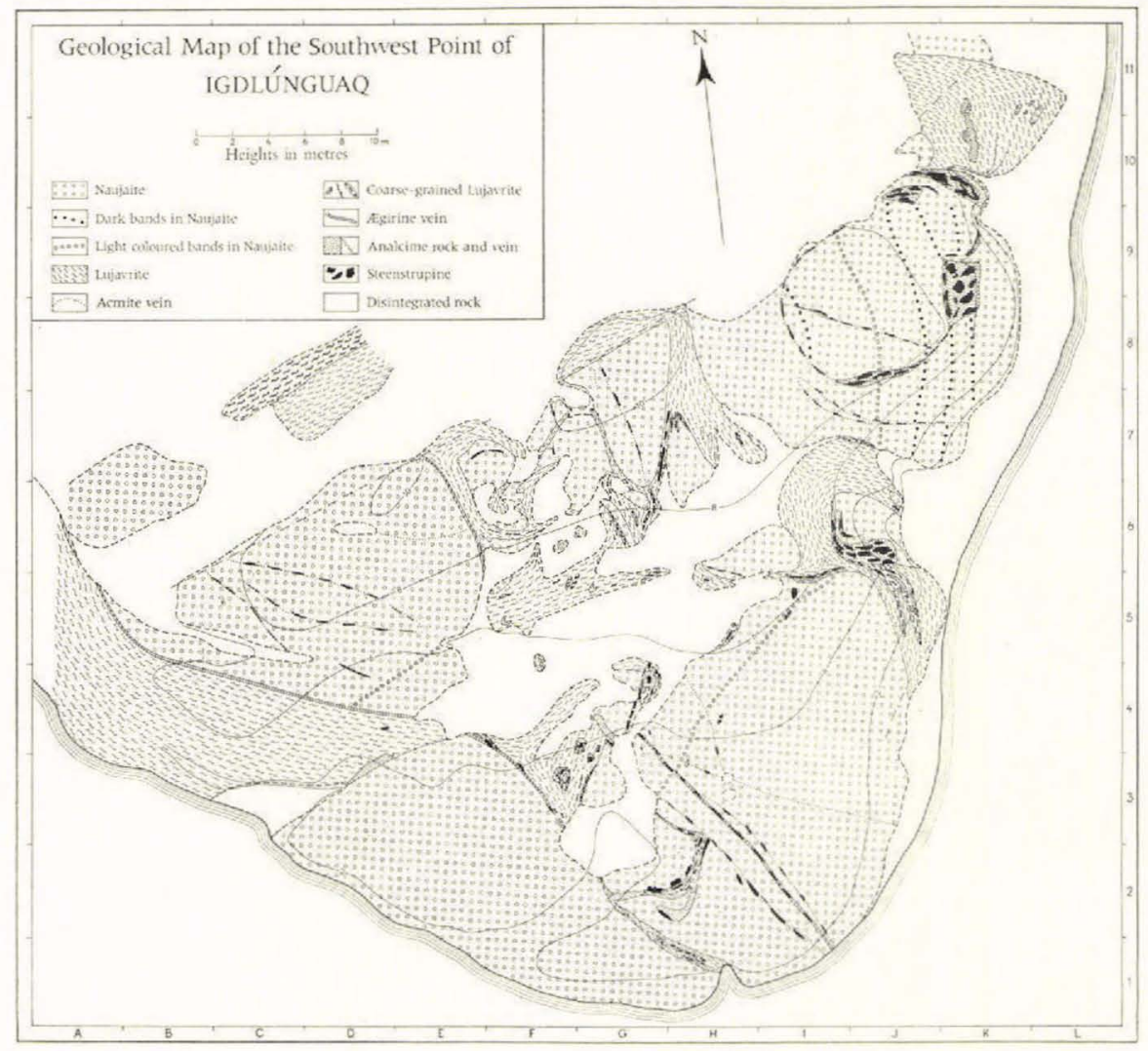

Fig. 2. Geological map of the Southwest point of Igdlunguaq. (Reproduced from Sorensen, 1962).

are regarded as having been formed simultaneously with the mise en place of the lujavrite. The patches containing analcime, etc. are most probably slightly later than the mise en place of the lujavrite and are formed partly from the residual liquids expelled from the lujavrite.

3. Light coloured veins composed of the minerals found in the coarse-grained patches of the above-mentioned brown and black veins. The light coloured veins often have concentrations of acmite and steenstrupine along the borders and are regarded as special cases of the light coloured, coarse-grained patches of the brown and black veins.

The following rare minerals have been found in the late veins: steenstrupine, sphalerite, schizolite, monazite, pyrochlore, igdloite, neptunite, chkalovite, britholite, lepidolite and thorianite. Eudialyte does not occur but pseudomorphs after it are fairly common, and consist of katapleite, pyrochlore, neptunite, ægirine/acmite, monazite, analcime and other minerals. 


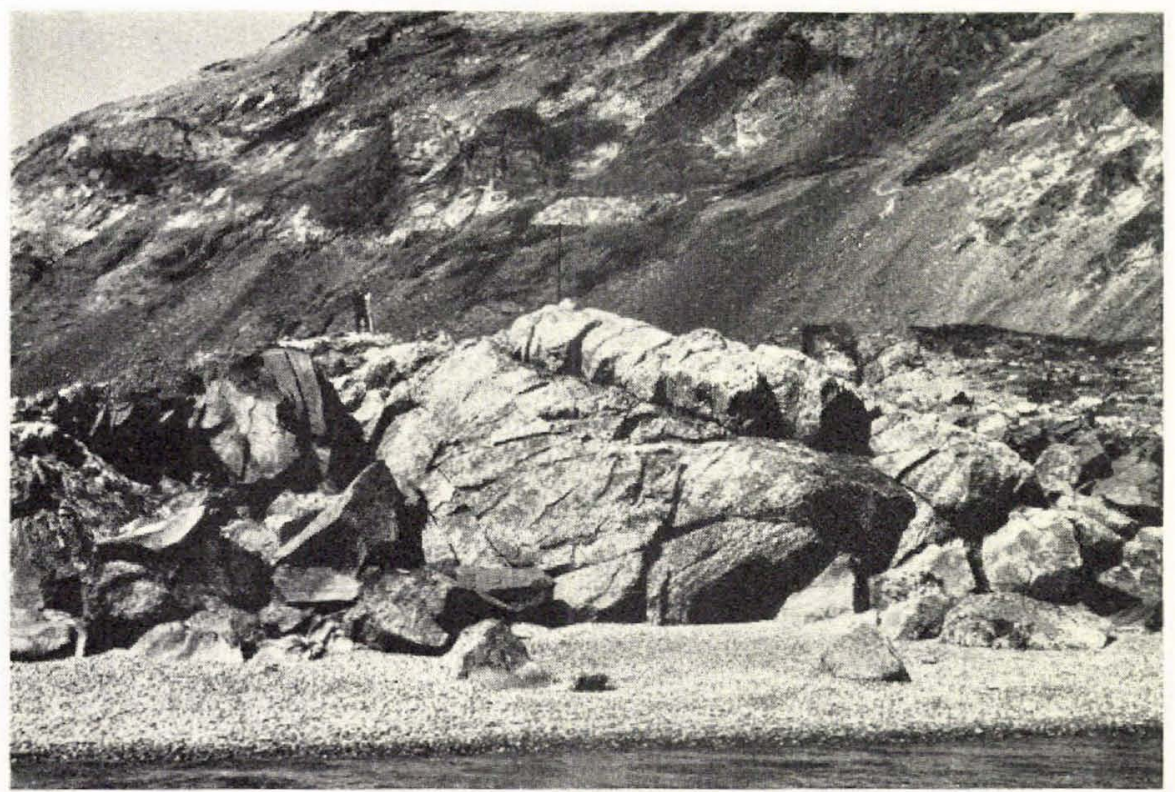

Fig. 3. The southwest point of Igdlúnguaq as seen from the east. The distinct slightly inclined fracture in the centre of the photograph (dipping towards the lower right corner) is the brown vein adjacent to which the ore minerals described in the text occur. (Reproduced from Sørexsen, 1962).

The mineral associations of the late veins indicate that the veins were formed under pegmatitic to hydrothermal conditions. A detailed description and discussion of these veins has been given by Sørensen (1962).

The niccolite and associated ore minerals occur in naujaite adjacent to an acmite-arfvedsonite vein at the coordinate position $\mathrm{J}-\mathrm{K}, 8-9$ in fig. 2. The vein is flat-lying with an easterly dip of about $30^{\circ}$. It is for a short distance parallel to the surface of the ground which explains its apparent thickness in fig. 2 (cf. figs. 3 and 4). The naujaite is banded and the vein is in contact with a eudialyte-rich band.

The acmite-arfvedsonite vein is a few centimetres thick and is composed mainly of black and brown fine-grained aggregates of acmite and/or arfvedsonite with light coloured, coarse-grained patches.

The brown parts of the vein often have a greenish tint and are composed of tiny needles of acmite with a subordinate amount of ægirine. The grains are sometimes arranged with their longest dimension parallel to the strike of the vein, but generally no preferred orientation can be seen. A few large black prisms of arfvedsonite, up to a few centimetres in length, are aligned parallel to the strike of the vein. 


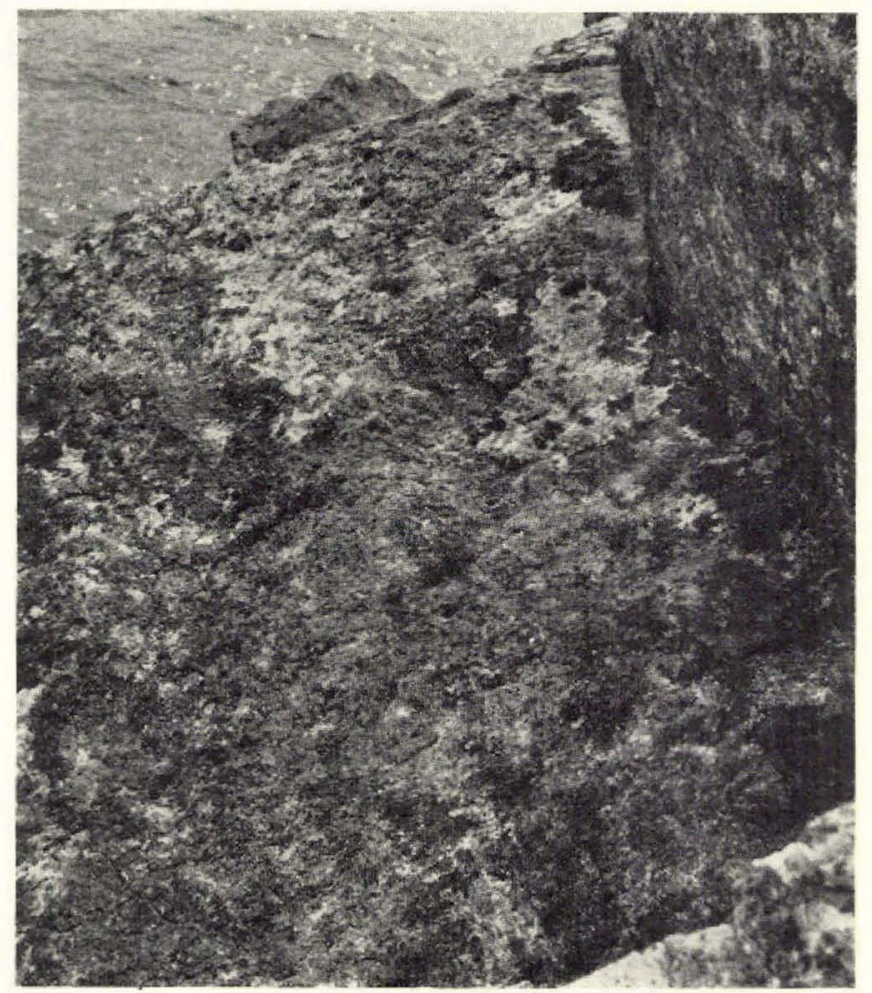

Fig. 4. The brown vein seen in fig. 3. The acmite-arfvedsonite vein rock has been partly removed by erosion so that white areas of the underlying naujaite are seen.

The black parts of the vein, in addition to the above-mentioned large arfvedsonite prisms, contain streaks of fine-grained arfvedsonite intergrown with acmite. The streaks are arranged approximately perpendicular to the walls of the vein.

The light coloured, coarse-grained patches often show an outer zone of small crystals of steenstrupine. In places the acmite-arfvedsonite matrix of the vein is lacking and the steenstrupine crystals then occur in direct contact with the naujaite. Generally, however, a thin rim of acmite and/or arfvedsonite separates the steenstrupine from the naujaite.

Inside this marginal steenstrupine zone the coarse-grained patches have a thin zone of yellow sodalite, which surrounds a coarse-grained core composed of large grains of analcime and natrolite with a minor amount of the rare mineral chkalovite (Sørensen, 1962). The analcime is white, grey or green and it has a distinct cubic cleavage. The large prisms of natrolite are white or light blue. White masses of fine-grained natrolite also occur. Other macroscopic constituents of the coarse-grained patches are: arfvedsonite, patches of yellow pyrochlore, white streaks 
of fine-grained igdloite associated with dark red neptunite and fine flakes of lepidolite.

Steenstrupine also occurs as small brown patches in the acmitic matrix of the vein.

Concentrations of small brown crystals of eudialyte locally occur along the contact between naujaite and vein. This eudialyte differs in colour from the red coloured eudialyte of the naujaite. The large eudialyte grains of the naujaite may also occur in direct contact with the vein. They are then brown in colour and are generally separated from the steenstrupine of the vein by a rim of acmite. Where steenstrupine forms the border of the vein the naujaite is rich in natrolite and devoid of eudialyte. Small impregnations of steenstrupine occur locally in the eudialyte-poor naujaite adjacent to the vein.

The nickel-arsenides and -antimonide occur as very small streaks and patches, a few millimetres long and generally less than one millimetre thick. They have been found only within a restricted area a few square centimetres in size. The ore minerals occur in cracks and along the cleavages of the sodalite and ægirine of the naujaite adjacent to the acmite-arfvedsonite vein. Patches of ore minerals also occur in a thin natrolite zone between the naujaite and vein. 


\section{PETROGRAPHY}

A petrographic description of the various rock types found at Igdlúnguaq has been given by SøRensen (1962). In the present paper only the rocks which are of direct importance for the discussion of the ore minerals will be considered.

\section{The Naujaite.}

The naujaite is composed mainly of poikilitic grains of microcline, ægirine and eudialyte with numerous inclusions of sodalite.

The crystals of sodalite, which are up to one centimetre across, are rich in microlites of arfvedsonite and ægirine. They are generally unaltered but sometimes partly replaced by aggregates of fine-grained natrolite ("spreustein").

The eudialyte occurs as large grains, several centimetres across, and crowded with inclusions of sodalite, sometimes to such an extent that the eudialyte is reduced to a fine interstitial network between the sodalite grains. The grain boundaries of the eudialyte are generally irregular, but crystal faces are locally developed. In the latter case the eudialyte may be zoned with alternating zones of eudialyte and mesodialyte parallel with the crystal faces. Some secondary katapleite occurs in the eudialyte.

Egirine forms large poikilitic grains which show evidence of deformation in the form of "columns" of slightly different optical orientation. The colour in thin section is green, but parts of the grains are brown and then consist of acmite (cf. SøRENSEN, 1962). Large areas composed of aggregates of fine-grained acmite enclose sodalite crystals in a poikilitic manner. Arfvedsonite is sometimes enclosed in the acmitic parts of the ægirine grains. Small individual prisms of arfvedsonite may have inclusions of acmite.

The large platy grains of microcline display the albitic chess board twinning which is so characteristic of the microclines found in agpaitic rocks (cf. SøRENSEN, 1962).

Large grains of nepheline with small inclusions of microcline and arfvedsonite are surrounded by fine-grained natrolite.

\section{The Contact Zone between the Naujaite and the Acmite-Arfvedsonite Vein.}

This zone is composed mainly of natrolite and analcime with inclusions of sodalite.

The natrolite occurs as large prismatic crystals, up to one centimetre long, and as aggregates of many small grains which are fairly equigranular.

Adjacent to the vein the large poikilitic ægirine grains of the naujaite are often deformed. Where the grains happen to occur at approximately right angles 
to the vein walls the broken-off parts of the grains appear to have been dragged into a position parallel to the vein. In other cases the ends of the ægirine crystals abutting the vein pass into acmite crowded with small flakes of a brown mica. The ægirine and acmite parts of these grains show a uniform optical orientation.

The ægirine of the natrolitic contact zone and of the adjoining naujaite is intergrown with arfvedsonite in a way indicating that it has been partially replaced by the latter mineral. Furthermore, large grains of arfvedsonite of this border zone contain small inclusions of acmite which, in restricted areas, all have the same optical orientation. This indicates that the arfvedsonite replaces aggregates of acmite. This acmite can have green cores.

Concentrations of small eudialyte crystals occur in the contact zone along the vein. This eudialyte is of the same type as that of the lujavrites having irregular, vein-like areas of mesodialyte. The crystals are generally altered into rust pigmentation, katapleite and other secondary minerals which are the cause of the brown colour seen in the hand specimen.

Small rust coloured grains of steenstrupine are occasionally seen in the contact zone.

In one place aggregates of small rounded grains of an apatite mineral of britholitic type (cf. Danø and SøREnSEn, 1959) have been observed in a groundmass rich in analcime. These grains are associated with small prisms of rgirine and arfvedsonite, the latter often forming homoaxial rims around the former.

\section{The Acmite-Arfvedsonite Vein.}

The major part of the vein is composed of acmite and arfvedsonite.

The acmite occurs in aggregates of small grains which often show well-developed prism faces. The grains generally show no preferred orientation but, locally, they may parallel the vein walls. The acmite often has central green patches of ægirine and contains abundant small flakes of a brown biotitic mica. The acmite aggregates have interstitial grains of arfvedsonite.

Arfvedsonite occurs as large prisms arranged paralled to the vein, as streaks composed of small needles and as large, apparently crushed grains of an appearance intermediate between that of the large grains and the streaks. The large prisms are in some cases seen to grade into crushed grains which again grade into the streaks. The latter are orientated at right angles to the walls of the vein and they were formed by deformation of the large prisms.

The large arfvedsonite prisms contain inclusions of acmite with flakes of the brown mica; the latter mineral also occurs in the arfvedsonite adjacent to the acmite inclusions. The streaks of fine-grained arfvedsonite have small interstitial fibres of acmite. Between the "units" of the crushed arfvedsonite grains there are also aggregates of acmite fibres.

The relationship between the acmite and the arfvedsonite of the vein may be interpreted as follows: Along a zone of deformation in the naujaite the ægirine has been deformed, crushed and partially substituted by acmite. This acmite forms the matrix of the vein. Large grains of arfvedsonite have partly replaced the acmite and are orientated parallel to the walls of the vein. Subsequently these prisms have been crushed and rolled-out into streaks almost perpendicular to the walls of the vein. The interstitial acmite in these streaks may have been formed by crushing of the acmite inclusions in the large arfvedsonite prisms, but there may also have been a new formation of acmite at this stage. Probably connected with the deformation in the zone now occupied by the vein is the formation of micro gash joints in 
the sodalite adjacent to the vein. These gash joints are arranged along fractures approximately parallel to the vein.

In the natrolite zone between the acmite-arfvedsonite vein and the adjoining naujaite there are clusters of small grains of a brown mineral. It appears to form prismatic crystals with a distinct cleavage at right angles to the elongation. The mineral is optically negative with a very small optic axial angle. The absorption scheme is of the type seen in tourmaline and astrophyllite: the darkest colour (brownish green to dark) appears when the shortest dimension of the crystals is orientated parallel to the vibration direction of the polarizer, while in the reverse position lighter colours (brown or reddish brown) appear. The "prisms" are connected with stages of transition into the above-mentioned flakes of a biotitic mica and the mineral is therefore most probably biotite.

The acmite-arfvedsonite rocks of the vein have a minor amount of interstitial analcime and natrolite. Accessories are steenstrupine, neptunite, britholite and, in rare cases, small eudialyte crystals of lujavritic type. There may also be pseudomorphs after eudialyte which are rich in plates of katapleite.

The coarse-grained, light coloured parts of the vein are made up of large grains and aggregates of small grains of natrolite, large analcime grains, large sodalite grains, schizolite, lepidolite, arfvedsonite, acmite, neptunite, pyrochlore, igdloite, chkalovite and steenstrupine.

The large grains of natrolite may display an irregular extinction.

The sodalite, which is yellow in the hand specimen, is free of dark microlites and thus differs from the sodalite of the naujaite. It contains $0.55 \% \mathrm{~S}$ and may be termed hackmanite (SøRENSEN, 1962).

Igdloite and pyrochlore occur along fractures and are associated with neptunite and a red micaceous mineral. They form fine-grained streaks and aggregates. The pyrochlore may occur as rims to the steenstrupine crystals.

Steenstrupine occurs in the contact between the acmite-arfvedsonite rock and the coarse-grained rock. It has irregular boundaries with the arfvedsonite and acmite, whereas crystal faces are developed towards the analcime, natrolite and sodalite of the patches. The steenstrupine contains inclusions of acmite and arfvedsonite. The arfvedsonite adjacent to and enclosed in the steenstrupine is of ten separated from the latter mineral by a rim of acmite.

The steenstrupine crystals have yellowish grey, isotropic cores and strongly coloured anisotropic marginal zones. The steenstrupine may be associated with remnants of pseudomorphs after eudialyte which are mainly composed of a pigmentary substance in a groundmass of analcime.

The coarse-grained rock has white, fine-grained patches composed of very fine-grained natrolite and some analcime with inclusions of strongly deformed microcline.

The ore minerals to be described in this paper occur in the natrolite-rich contact zone between naujaite and acmite-arfvedsonite vein. The natrolite penetrates the sodalite of the naujaite and contains inclusions of that mineral.

Several small nests of ore minerals occur as lines of inclusions in the natrolite. They also occur along the cleavages of ægirine and arfvedsonite and in cracks in the sodalite. The minerals surrounding the ore grains are rust coloured.

The ore in the fractures in sodalite is often separated from the latter by a thin rim of natrolite. Analcime may also replace the sodalite.

The ore-bearing natrolite rock contains small grains of britholite, schizolite, arfvedsonite, ægirine, steenstrupine and remnants of large grains of naujaitic ægirine. 


\section{DIAGNOSTIC PROPERTIES OF THE ORE MINERALS}

The material available for the present study is very scanty and consists only of two hand specimens of naujaite, showing a few spots with very fine-grained impregnations of ore minerals. This material has allowed the preparaion of only a few polished sections.

\section{Galena.}

This mineral is easily recognized by its greyish white colour, isotropic character, low hardness, and low reflectivity as compared with the accompanying minerals.

\section{Niccolite and Breithauptite.}

These two minerals have such distinct colours and anisotropy effects that confusion with other minerals is not likely to occur.

In oil niccolite shows a distinct pleochroism with yellowish pink to light brownish pink colours. The reflectivity is high and about equal to that of breithauptite. Anisotropy effects are strong; the colours under crossed nicols show distinct brownish and bluish tints. The hardness of the mineral is about the same as that of breithauptite; both these minerals are softer than skutterudite, maucherite and löllingite.

Breithauptite is distinguished from niccolite by a stronger pleochroism with characteristic light pinkish to bright pinkish violet colours in oil. Anisotropy effects are very strong, the mineral shows distinct bluish and violet red colours under crossed nicols. The identity of the breithauptite has been confirmed by X-ray powder diagrams, which show patterns identical to those given for the mineral by HewitT (1948).

\section{Maucherite.}

In oil the colour of this mineral is bluish grey in comparison with niccolite and breithauptite; in contact with breithauptite it appears 
more brownish grey, and in comparison with löllingite it appears distinctly brownish grey. Pleochroism is almost imperceptible in air, and when observed in oil it is very weak. The reflectivity is about equal to or somewhat higher than that of niccolite and breithauptite. Anisotropy effects are very weak in air, but distinct in oil; colour effects under crossed nicols range from dark to light grey. The mineral is harder than niccolite, breithauptite and skutterudite, but softer than löllingite. Twinning has occasionally been observed.

Etching with $\mathrm{FeCl}_{3}$ stains weak brown to iridescent; $\mathrm{HNO}_{3}$ stains black under effervescence. $\mathrm{HgCl}_{2}, \mathrm{HCl}, \mathrm{KCN}$ and $\mathrm{KOH}$ give negative results after 1 minute. (Reagents after SHorT, 1948).

The mineral occurs finely intergrown with breithauptite and löllingite and it has not been possible to secure pure material for X-ray analysis. The diagrams of the impure material show the lines of breithauptite and löllingite besides that of the mineral in question, while some admixture of silicates is also suspected. The strongest lines in the diagram, which are apparently due to the mineral here under consideration, are given below.

\begin{tabular}{ll}
$\begin{array}{l}\text { Strongest d-lines and } \\
\text { intensities of presumed } \\
\text { maucherite }\end{array}$ & $\begin{array}{l}\text { Strongest d-lines and } \\
\text { intensities of synthetic } \\
\text { maucherite (HEYDING and } \\
\text { CALVERT, 1957) }\end{array}$ \\
\hline 2.599 (strong) & $2.68(80)$ \\
1.983 (strong') & $2.01(100)$ \\
1.723 (moderately strong) & $1.71(90)$
\end{tabular}

It appears that the values of the strongest d-lines of the presumed maucherite deviate slightly from those given for the mineral in the literature (PEAcock, 1940; Heyding and CALvert, 1957). In respect of this Mrs. M. DANø of the Mineralogical Museum in Copenhagen, to whom the authors are indebted for the X-ray photographs, has kindly commented as follows: "If some substitution of Ni or As by other elements has taken place in the maucherite, a small change in the intensity ratio and the positions of the d-lines might be expected. However, with the indices assigned by HeYding and Calvert (1957) to the strongest lines of their maucherite diagram, it appears not possible to account for the deviations of our diagram by assuming variations in the lattice constants of the mineral, and yet maintain a reasonable agreement between calculated and observed d-values. More material is desirable for further analysis".

YUND (1961) has pointed out that the artificial compound $\mathrm{Ni}_{5-\mathrm{x}} \mathrm{As}_{2}$ has similar optical properties as maucherite, so that the possibility of misidentification exists. Comparison of our X-ray data with that of $\mathrm{Ni}_{5-\mathbf{x}} \mathrm{As}_{2}$ (HEYDING and Calvert, 1957) shows that our mineral is not $\mathrm{Ni}_{5-\mathrm{x}} \mathrm{As}_{2}$. 
As Yund states, a final solution to the subtle structural differences in maucherite cannot be given until a structural analysis has been made in order to determine the atomic position and parameters. YunD's data suggest that a metastable phase forms during rapid cooling of $\mathrm{Ni}_{11} \mathrm{As}_{8}$ from above $700^{\circ} \mathrm{C}$, and that "additional reflections" recorded on powder diagrams at room temperature are from this metastable phase. Unfortunately too many impurities interfere in the diagram of our alleged maucherite, so that the presence or absence of these "additional reflections" cannot be verified. Quoting YUND again: "Because the number of possible reflections from the unit cell of maucherite is very large, the agreement of the observed and calculated d-values may be fortuitous, and the space group determined on the basis of powder patterns alone may be incorrect."

From its mineral paragenesis, mineralogical and textural habits, optical properties and etch tests (UYTENBOGAARDT, 1951; RAMDOHR, 1960), the identity of the mineral with maucherite is probable. Although due to the scantiness of the material its X-ray identification has to remain incomplete, the mineral is presumably to be referred to as maucherite, unless it eventually appears to represent some hitherto unknown modification or new mineral with properties very similar to those of maucherite.

\section{Lö1lingite.}

When observed in oil the mineral shows a weak pleochroism in distinctly bluish white colours. Its reflectivity is about equal to that of maucherite. Anisotropy effects are strong and show distinct colour effects ranging from dark brownish to dark bluish. The mineral is harder than niccolite, breithauptite and maucherite.

$\mathrm{HNO}_{3}$ etches slowly without effervescence and stains light brown. $\mathrm{FeCl}_{3}, \mathrm{HCl}, \mathrm{KCN}, \mathrm{HgCl}_{2}$ give negative results after 1 minute. (Reagents after Short, 1948).

The löllingite occurs as blades enclosed in maucherite, which seems to be an unusual habit for the mineral. The distinct bluish tint and the etch reactions make confusion with rammelsbergite or pararammelsbergite unlikely, but from ore-microscopic observations alone the mineral cannot be safely distinguished from safflorite.

$\mathrm{X}$-ray powder diagrams of maucherite-löllingite-breithauptite mixtures show the five strongest d-lines of löllingite (PEACOCK, 1941) as weak lines, which is consistent with the small amount of the löllingite contained as blades in the maucherite.

\section{Skutterudite.}

This mineral has a greyish white colour, perhaps with a somewhat yellowish tint in oil. Its reflectivity is high and approximately equal to 
that of niccolite and breithauptite. The mineral is isotropic. It is harder than niccolite and breithauptite, but softer than maucherite. Taking into account the mineral paragenesis, confusion with other minerals is not likely to have occurred.

\section{Gudmundite.}

When observed in oil the mineral shows a weak pleochroism in white to somewhat more pinkish white colours. Its reflectivity is very high, higher than that of breithauptite. Anisotropy effects are distinct to strong; colour effects under crossed nicols range from brownish to bluish grey. The mineral is softer than breithauptite. The grains often show a tendency to form prismatic crystals. Twinning is often observed. The ore-microscopic properties of the mineral are sufficiently conspicuous to warrant its identification as gudmundite.

\section{Ilvaite.}

The very few, small, disseminated grains of this mineral usually do not occur associated with the arsenides and the breithauptite. The mineral, which often shows a tendency to form prismatic crystals, has a very distinct pleochroism in characteristic pinkish grey and bluish grey colours. Its reflectivity is low; reddish internal reflections are common. Anisotropy effects with reddish, pinkish and bluish colours are strong. This mineral has not been observed in thin sections of the rock. 


\section{TEXTURAL RELATIONS OF THE ORE MINERALS}

\section{Relations between the ore minerals and the other rock components.}

The ore minerals appear in very small, extremely fine-grained and closely spaced aggregates or nests, which are often arranged in irregular strings. In sections the longest dimension of the ore nests rarely exceeds $1 \mathrm{~mm}$ and is usually less than $0.5 \mathrm{~mm}$. In general the ore aggregates occur interstitially between the silicates and along cracks and cleavage planes in the latter. Sometimes stringers of ore nests are enclosed in sodalite-natrolite intergrowths (Plate 1, fig. 1). In the latter intergrowths closely spaced patches of natrolite, irregular in shape but often showing concave boundaries, form a network enclosing "meshes" of somewhat rounded (convex boundaries) sodalite areas. The ore aggregates, occurring locally as patches in these intergrowths; are often of the same form and size as the natrolite patches, but they are more sparsely distributed. Occasionally some natrolite occurs in very fine veinlets along the boundaries between an ore aggregate and the surrounding sodalite. These textures suggest that in all probability the sodalite has been penetrated and replaced along irregular cracks by the ore minerals and, contemporaneously and/or subsequently, by the natrolite.

Ilvaite is an accessory mineral in the rock and generally it does not occur associated with the Ni-Co minerals. However, an occasional observation of a slightly corroded ilvaite grain enclosed in an ore nest suggests that the ore minerals may be later than the ilvaite.

\section{Zonal textures in ore aggregates.}

Most of the ore aggregates consist mainly of intergrowths of maucherite and breithauptite (Plate I, fig. 1; Plate II, figs. 2 and 4; Plate III, fig. 1, 2, 3 and 4; Plate IV, fig. 1), which form the bulk of the ore minerals. A number of aggregates contain in addition niccolite and occasionally also gudmundite. The latter aggregates commonly exhibit 
zonal textures (Figs. 5, 6, 7 and 8; Plate I, fig. 2; Plate II, figs. 1 and 3; Plate IV, fig. 2 and 3).

Skutterudite and niccolite are found exclusively in the central parts of zoned aggregates. The two minerals are often intimately intergrown with very fine-grained maucherite. A zone of the latter mineral nearly always surrounds the skutterudite-niccolite aggregates. The maucherite often contains oriented inclusions of löllingite blades. An outer rim of breithauptite usually surrounds the maucherite, but frequently the maucherite and breithauptite zones merge into another and form a mixed zone (fig. 6). Gudmundite sometimes forms rims and small crystals around breithauptite-maucherite aggregates (Plate IV, fig. 2). The different zones have variable relative widths. Sometimes niccolite is surrounded by extremely thin rims of maucherite and breithauptite; in other instances broader zones of the latter minerals enclose only a small patch of niccolite.

\section{Skutterudite-niccolite relationships.}

Skutterudite mostly occurs as corroded fragments surrounded and irregularly veined by niccolite, which is clearly the younger of the two minerals. Skutterudite is present only in rather small quantities and often the central parts of the zoned aggregates consist only of niccolite.

Some skutterudite fragments show thin $(0.01 \mathrm{~mm})$ replacement or reaction zones of niccolite, which show constant thicknesses and exactly follow the boundaries between skutterudite and certain maucheritebreithauptite myrmekites ${ }^{1}$ ) (figs. 5 and 6 ). These niccolite reaction zones are apparently contemporaneous with or later than the adjacent maucherite-breithauptite myrmekites. However, as will be shown in the next paragraph, the bulk of the niccolite formed earlier than the maucherite. The earlier niccolite often appears to have been recrystallized, whereas the reaction zones of later niccolite along the skutterudite

1) The term myrmekite is here used in a formal, descriptive sense to denote those intergrowths of minerals showing some kind of resemblance to the well-known quartz-plagioclase intergrowths, to which the name myrmekite was first applied by SEDERHOLM $(1897$, p. 113). This wide use of the term does not conform to the strict meaning of the word and in petrographic literature the term is generally used in a more restricted sense. In ore-microscopic descriptions the term myrmekite has been applied to various intergrowths, which have also been described as graphic, sub-graphic, eutectic, pseudo-eutectic, eutectoid, granophyric, symplectitic, diablastic, etc. These terms have been used partly as synonyms for myrmekite, and partly in special genetic senses. RAmDOHR (1945) used myrmekitic intergrowth as a nongenetic term to include most of the above-mentioned intergrowths, and for convenience his usage is followed here. The predominant component in the intergrowth is mentioned first, so that maucherite-breithauptite myrmekite refers to a myrmekitic intergrowth consisting mainly of maucherite. 


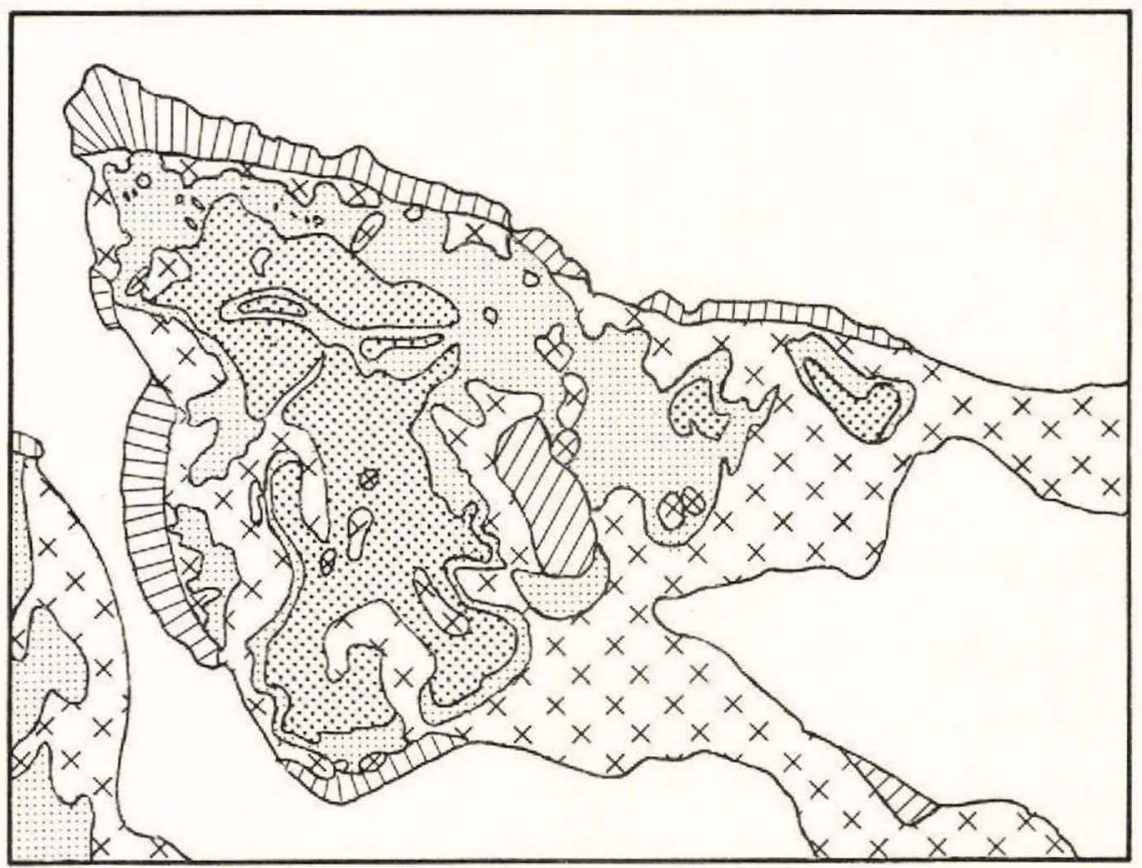

Fig. 5. An aggregate of niccolite (finely stippled) and skutterudite (coarsely stippled) surrounded by zones of maucherite (crosses) and breithauptite (ruled). A part of the maucherite occurs as fine-grained, non myrmekitic aggregates along the outer borders of the niccolite area. This maucherite has presumably originated from the partial dissociation of niccolite; the maucherite so formed has gathered together to form an irregular, discontinuous zone along the boundaries of the niccolite aggregates with the outer breithauptite rim which shows columnar textures. The outer breithauptite rim is believed to have been formed almost contemporaneously with the partial dissociation of niccolite, which reaction probably involved a decrease in volume of the solids. On the other hand, the larger areas of coarser-grained maucherite consist of maucherite-breithauptite myrmekites (in the figure the myrmekite and non-myrmekitic maucherites have not been differentiated; they are uniformly indicated by the notation with crosses) which have apparently formed later than the breithauptite rim. At some places the latter rim appears interrupted by the myrmekites. The inclusions (not drawn in the figure) in the myrmekitic maucherites consist mainly of breithauptite, while some niccolite inclusions are also found. Note also the narrow niccolite zones (in the figure about $1 \mathrm{~mm}$ in width and not especially delineated) along the skutterudite-maucherite boundaries. These thin zones do not show signs of recrystallization and they are presumably younger than the larger niccolite areas, which are made up of a recrystallized, finely granular aggregate with very fine-grained interstitial maucherite (not indicated in the figure,

but compare plate II, fig. 2). (Drawn from a photograph, $160 \mathrm{x}$ ).

grain boundaries have not been affected by recrystallization. Furthermore, maucherite networks typically occur in the earlier niccolite (see below), but they have not been observed in the reaction zones of later niccolite. 


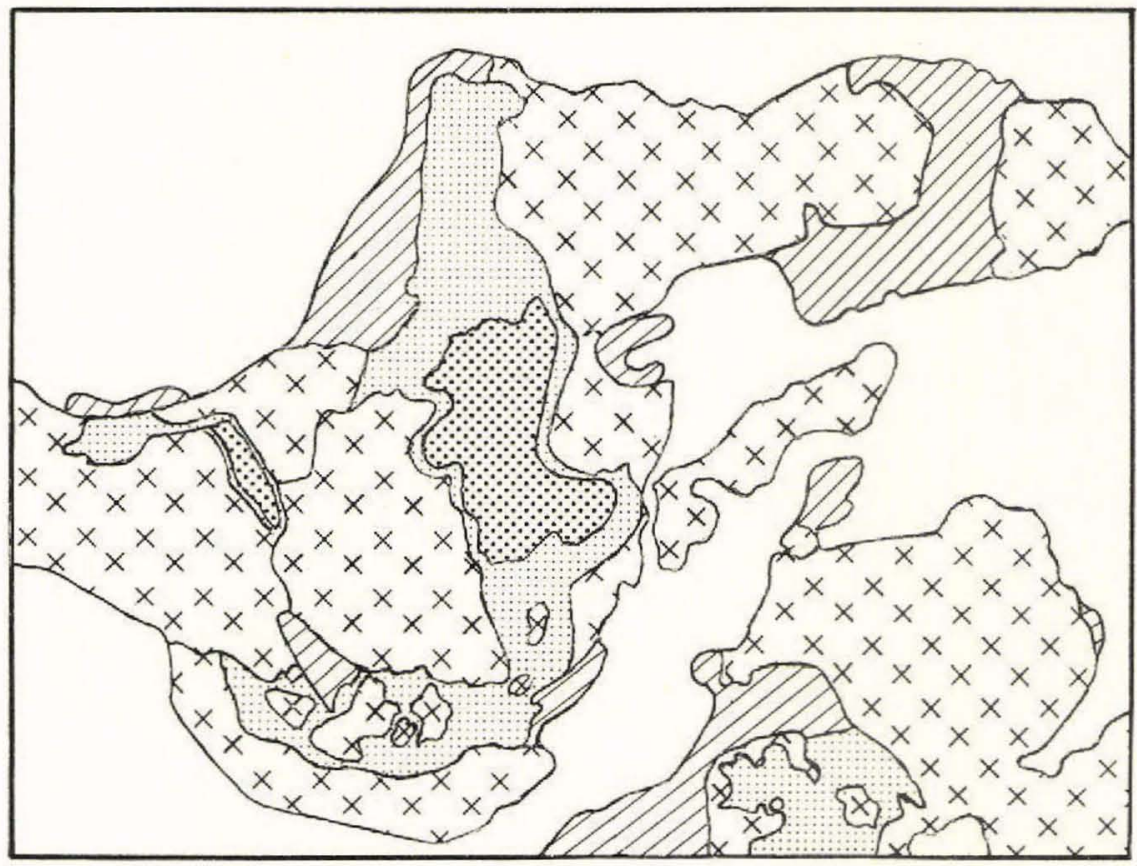

Fig. 6. Broad mixed zones of breithauptite (diagonally ruled) and maucherite (crosses) surrounding an aggregate of skutterudite (coarsely stippled) and niccolite (finely stippled). A narrow zone of niccolite (about $1 \mathrm{~mm}$ wide in the figure and not especially delineated) follows the grain boundaries between skutterudite and maucherite. This zone consists of a single optically continuous individual, whereas the other areas of niccolite consist of a fine-grained, presumably recrystallized aggregate. The maucherite, skutterudite and recrystallized niccolite aggregates contain breithauptite inclusions (not drawn in the figure) and appear as myrmekitic intergrowths. In the niccolite areas the uniformly oriented breithauptite inclusions occur interstitially befween the niccolite grains, but this feature is not shown in the figure. (Drawn after a photograph, $160 \mathrm{x}$ ).

\section{Skutterudite-maucherite and niccolite-maucherite relationships; cell or pseudo-cell textures.}

Sometimes the niccolite forms a single comparatively large grain, maucherite and breithauptite rims being either absent or extremely narrow. However, more often the niccolite occurs in finely granular aggregates, which frequently are veined by very thin, intergranular veinlets or irregular stringers of maucherite (figs. 7 and 8; Plate I, fig. 2; Plate II, figs. 1 and 3). Skutterudite, if present, is sometimes also traversed by the fine maucherite veinlets, which also are often found along the skutterudite-niccolite boundaries. The niccolite of the 
niccolite-skutterudite aggregates with the network of maucherite veinlets are surrounded by a zone of varying thickness of maucherite grains (figs. 5, 7 and 8; Plate I, fig. 2; Plate II, figs. 1 and 3). The boundaries between this maucherite zone and the enclosed niccolite and skutterudite usually show irregular, ragged outlines with apophyses grading into the network of fine maucherite veinlets. The maucherite network occasionally extends over almost the whole of the niccolite area, but is more often confined to those marginal parts of the niccolite, which

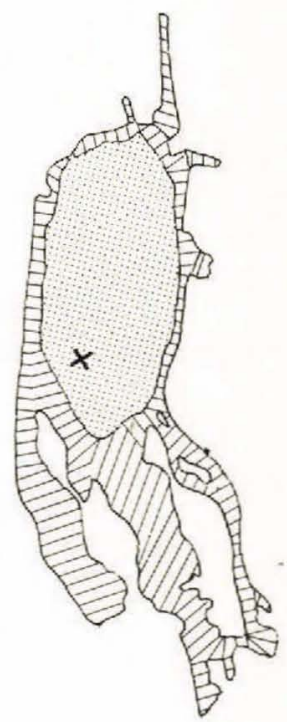

Fig. 7. For explanation see Plate II, fig. 1 and accompanying text.

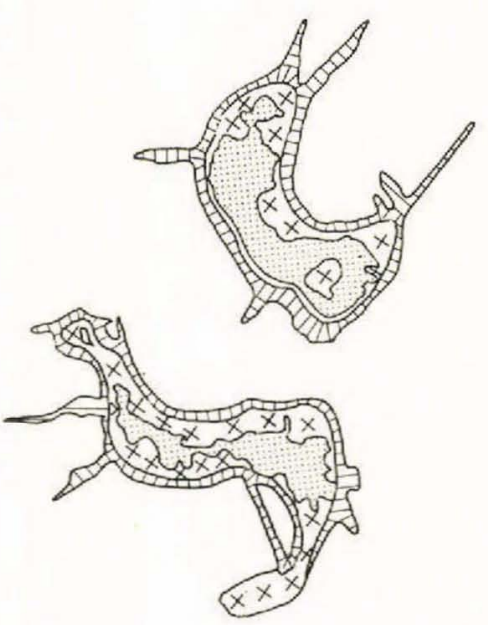

Fig. 8. For explanation see Plate II, fig. 3 and accompanying text.

adjoin the maucherite zone. The central parts of the niccolite areas are often free of maucherite. In the latter instances only the peripheral parts of an originally larger niccolite grain have apparently recrystallized. Recrystallized aggregates of niccolite sometimes still show the subhedral outlines of the original crystals (fig. 7; Plate I, fig. 2; Plate II, fig. 1).

Sometimes a well developed zone of maucherite surrounds a recrystallized fine-grained niccolite aggregate, of which the maucherite veinlets and stringers have apparently been drained off to form the maucherite rim, so that the niccolite aggregate is now barren of the network of interstitial maucherite veinlets. In general, several gradational forms have been observed between thin maucherite zones surrounding recrystallized niccolite aggregates with well developed mau- 
cherite networks and the better developed maucherite zones surrounding niccolite aggregates devoid of the maucherite networks (compare Plate I, fig. 2 with fig. 8 and Plate II, fig. 3).

Some granular breithauptite frequently occurs in comparatively broad zones of coarser-grained maucherite (figs. 5 and 6). In these cases the maucherite veinlets in the niccolite-skutterudite areas show a tendency to thicken and to form irregularly shaped interstitial grains, which often enclose small inclusions of breithauptite, and occasionally of niccolite and skutterudite, in a myrmekitic fashion. The resulting textures are similar to those of the maucherite-breithauptite myrmekites to be described in a later section. These maucherite zones often merge into breithauptite zones containing some maucherite and frequently they form an outer mixed zone of breithauptite and maucherite (fig. 6).

The textural relations clearly indicate that the maucherite has in general been formed later than the niccolite and niccolite-skutterudite aggregates. However, as described before, within the latter aggregates some replacement of skutterudite by niccolite took place contemporaneously with the formation of maucherite-breithauptite myrmekites.

The niccolite-maucherite networks show a resemblance to the cell or pseudocell textures produced artificially by HAWLEY and HEwITT (1948 a, b; HEwITT, 1948; see also HAwLEy, STANTON and SMITH, 1961) by heat treatment of solid solutions of NiAs with up to 30 atomic per cent $\mathrm{NiSb}$. By reference to these experiments the network or cell textures of maucherite in niccolite observed in our specimens may be ascribed to the partial dissociation of $\mathrm{NiAs}$ (niccolite) into $\mathrm{Ni}_{3} \mathrm{As}_{2}$ (maucherite) and arsenic vapour.

As indicated by the relations between the degrees of development of the maucherite rims and the enclosed maucherite networks, the thinner non-myrmekitic, maucherite zones have presumably resulted from the segregation towards grain boundaries of the maucherite formed by the partial dissociation of the enclosed niccolite. However, in the broader zones of maucherite associated with breithauptite, the formation of myrmekitic maucherite containing breithauptite inclusions most probably should be referred to the later period of maucherite crystalloblastesis, which is subsequent to the formation of breithauptite (see later).

The formation of niccolite reaction zones at the expense of skutterudite invol ved the liberation of As, as was also the case with the partial dissociation of niccolite. Those maucherite-breithauptite myrmekites, which have given rise to the formation of niccolite reaction zones along the boundaries with skutterudite, are believed to have been formed at a comparatively early stage of the period of maucherite crystalloblastesis, when the prevalence of higher temperatures permitted higher arsenic partial pressures to exist in equilibrium with the solid phases.

\section{Skutterudite-breithauptite and niccolite-breithauptite}

\section{myrmekites.}

Occasionally the skutterudite and niccolite contain very small, blebor worm-like inclusions of breithauptite. The inclusions in niccolite and 
skutterudite grains which adjoin each other often show the same optical orientation. Breithauptite inclusions sometimes occur partly enclosed in niccolite and partly in skutterudite. With crossed nicols it often appears that the niccolite consists of a finely granular recrystallized aggregate, in which the breithauptite inclusions are mostly intergranular.

The latter observation suggests that the breithauptite inclusions are later than the niccolite and, therefore, also later than the skutterudite. A replacement origin seems most probable for these myrmekitic intergrowths.

\section{Breithauptite rims and crack-fillings with columnar textures.}

The broader zones of breithauptite consist of comparatively coarsegrained granular crystals, often intergrown with maucherite-breithauptite myrmekites. These broader zones do not show the columnar textures described here; the latter are found only in some of the thinner, finegrained, outer rims of breithauptite in zoned aggregates with niccolite and maucherite in the central parts (figs. 5, 7 and 8; Plate II, figs. 1 and 3). These rims consist of fine, columnar or tabular crystals with parallel arrangement, their longest dimensions being perpendicular to the outer boundaries of the enclosed maucherite zone and to the walls of the ore nests. Sometimes the rims are only partially developed. Mostly the rims show an approximately constant width and congruous, smooth and sharp inner and outer boundaries. Locally, rims of columnar breithauptite appear interrupted and replaced by grains of maucheritebreithauptite myrmekite (fig. 5).

Similar columnar textures are exhibited by some very thin breithauptite veinlets, which connect different ore nests with each other. Sometimes a number of radially arranged veinlets of columnar breithauptite have been observed around zoned ore aggregates (Figs. 7 and 8; Plate II, figs. 1 and 3). These radial veinlets are often wig-shaped, tapering off outwardly. The breithauptite rims with columnar textures often appear connected to veinlets with columnar textures.

The columnar textures and the shapes and disposition of the fine veinlets indicate their origin as crack-fillings. The radial disposition of some veinlets around ore nests suggests that these cracks may be due to increased pressure and expansion of the system contained in the ore nests. On the other hand, the textures, shapes, and disposition of the breithauptite rims suggest an origin of these rims as fillings of concentric cracks, probably due to shrinkage. It is suggested that at a certain period the volume of the crystallizing system in the ore nests tended to increase because of the development of a vapour phase, whereas the volume of the solid phases remained constant or was decreased. This period may presumably be correlated 
with the inferred partial dissociation of niccolite, involving the formation of maucherite and arsenic vapour.

Although the rims of columnar breithauptite are believed to have been formed subsequently to the formation of maucherite by partial dissociation of niccolite, they are apparently older than the maucherite-breithauptite myrmekites. The formation periods of maucherite and breithauptite presumably overlap to a considerable extent.

\section{Myrmekitic and bladed intergrowths of maucherite and breithauptite.}

In the zoned ore nests coarser-grained maucherite and breithauptite zones consisting of aggregates of breithauptite and maucherite-breit-

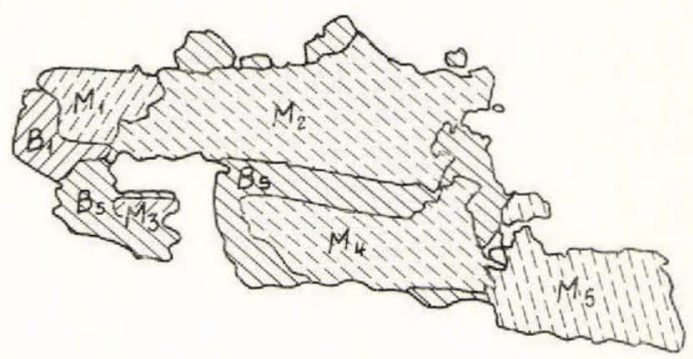

Fig. 9. For explanation see Plate II, fig. 2 and accompanying text.

hauptite myrmekite apparently represent an intermediate form between the finer-grained zones of maucherite and of breithauptite on the one hand, and the aggregates consisting mainly of maucherite-breithauptite myrmekites on the other hand. The latter aggregates do not show well defined zonal textures (Plate I, fig. 1; Plate II, figs. 3 and 4; Plate III, figs. 1, 2, 3 and 4; Plate IV, fig. 1). Very often a heterogranular aggregate of breithauptite completely or partially surrounds one or more crystals of maucherite, which invariably contain numerous small inclusions of breithauptite in a myrmekitic fashion. In sections the inclusions show various shapes: drops, parallel streaks, hook- and comma-shaped forms. Some observations of possible significance may be conveniently enumerated as follows:

1) The maucherite-breithauptite myrmekites sometimes tend to form subhedral crystals with elongated, rectangular longitudinal sections and approximately square cross sections (e. g., fig. 9; Plate II, fig. 2; Plate III, fig. 2). However, they occur more frequently as irregular, vein-like masses interstitial to breithauptite grains (e. g., Plate II, fig. 4) and occasionally enclosing areas of breithauptite. 


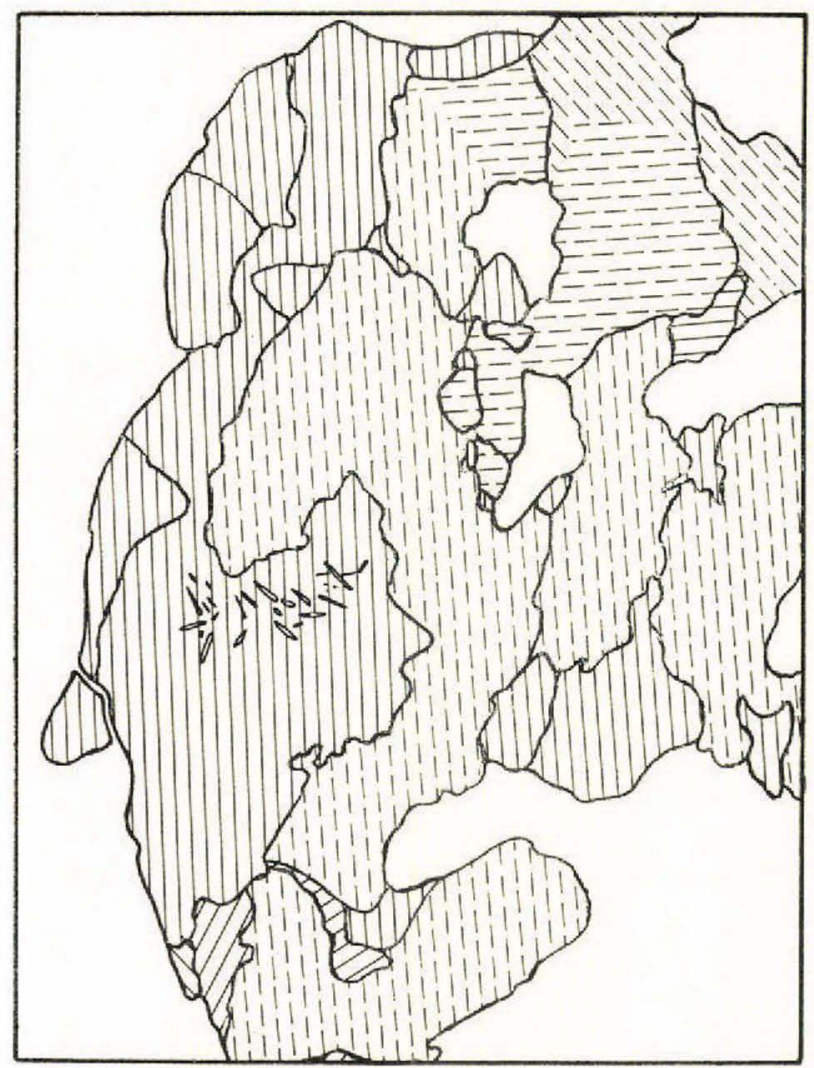

Fig. 10. For explanation see Plate III, fig. 1 and accompanying text.

2) Small inclusions of galena in breithauptite always show oval or rounded forms. However, where they are in contact with maucherite or löllingite, the latter minerals appear to have destroyed the originally smooth, rounded outlines of the galena inclusions, which were previously completely surrounded by breithauptite (Plate II, fig. 4).

3) The breithauptite inclusions in the maucherite generally show a uniform extinction. The optical orientation of the inclusions changes with that of the host. An adjoining breithauptite grain with the same optical orientation as the inclusions can usually be found (e. g., figs. 9, 10, 11 and 12; Plate II, figs. 2 and 4; Plate III, figs. 1 and 2).

4) Occasionally a maucherite-breithauptite myrmekite shows two or more spatially related groups of breithauptite inclusions which show different orientations seemingly related to those of adjoinning breithauptite grains (figs. 10 and 11). Mostly the inclusions appear optically slightly disoriented with regard to the adjoining breithauptite grains, and often they tend to assume a uniform optical orientation in the 


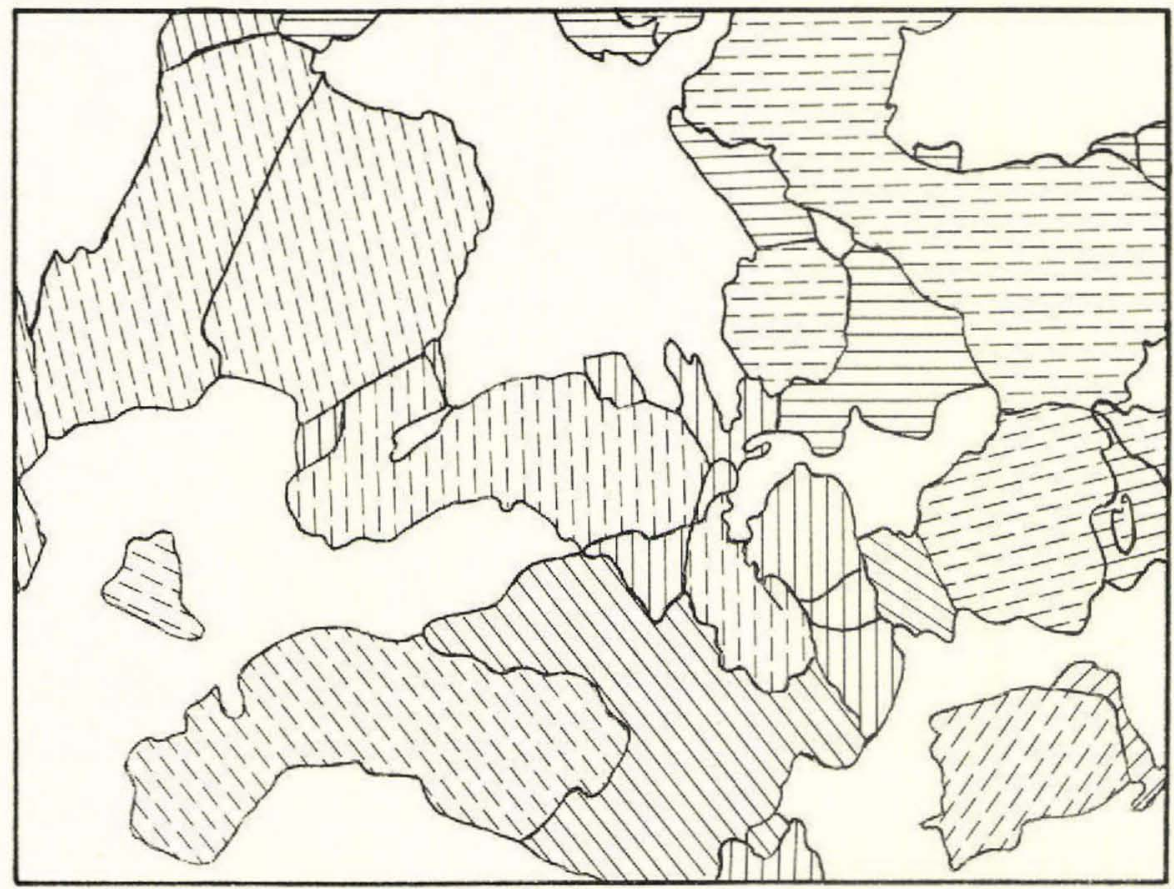

Fig. 11.

Fig. 11 and 12. Diagrammatic representations of the optical orientation of breithauptite inclusions in maucherite-breithauptite myrmekites and of the adjoining breithauptite grains. The different striation directions indicate different optical orientations of breithauptite grains. The directions of broken lines indicate the optical orientation of breithauptite inclusions in maucherite-breithauptite myrmekites. Spatially related breithauptite grains showing optical orientations differing only so slightly from each other that they can be grouped together as a "superindividual" are uniformly striated. Areas shown white consist of gangue material. The maucherite-breithauptite myrmekite $\mathrm{M}_{1}$ in fig. 12 has two groups of inclusions with different extinction positions. The myrmekite $\mathrm{M}_{2}$ contains breithauptite inclusions with an optical orientation similar to that of the adjoining part of $\mathrm{M}_{1}$ and to that of the breithauptite grain $B_{1}$. In other myrmekitic grains too a relation between the optical orientation of breithauptite inclusions and that of neighbouring breithauptite grains can be discerned. Note also the local development of finely granular breithauptite $(\mathrm{Bg})$ in fig. 12, which might be due to incipient recrystallisation. (Drawn after photographs, $160 \mathrm{x}$ ).

maucherite crystal. Sometimes the inclusions of breithauptite in two myrmekitic individuals bordering on the same breithauptite grain show the same or approximately the same optical orientation as the latter. In yet other instances two small myrmekitic crystals of maucherite appear enclosed in one breithauptite grain; the breithauptite inclusions in the myrmekite show slightly different optical orientations, not deviating much from that of the enclosing breithauptite. Furthermore, the optical orientation of breithauptite inclusions in twinned crystals 


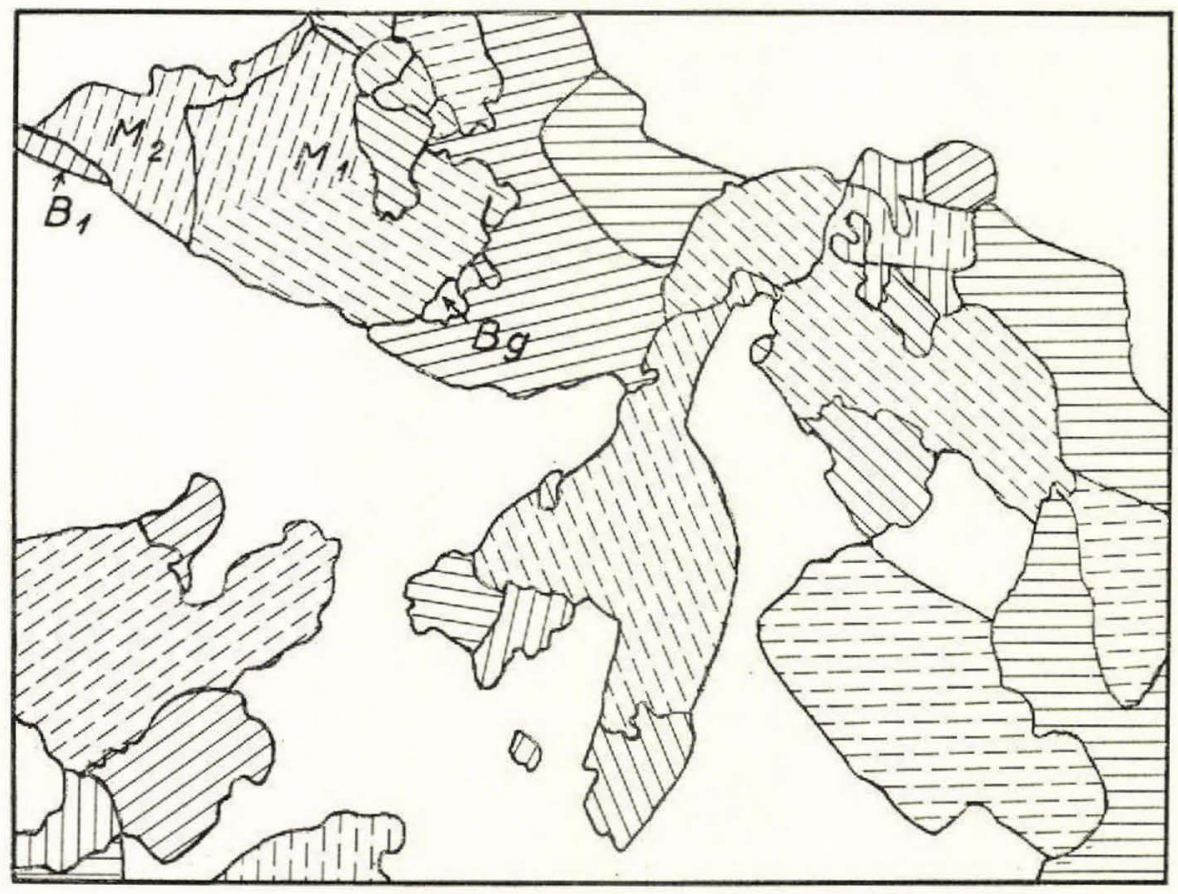

Fig. 12.

of maucherite changes with the orientation of the twinned individuals (Plate II, fig. 2; Plate III, fig. 2).

5) Generally the inclusions are regularly distributed in the central part of the maucherite crystals. A thin outer rim is either free of inclusions or contains only few of them (Plate II, fig. 2; Plate III, fig. 2). Sometimes a few of the worm-like inclusions traverse the outher parts of the crystal and make contact with the surrounding breithauptite.

6) Some ore nests contain only a single comparatively large crystal of breithauptite enclosing a small grain of maucherite-breithauptite myrmekite; other nests are entirely made up of maucherite-breithauptite myrmekites (Plate IV, fig. 1). Various intermediary proportions between these two extremes in the relative amounts of breithauptite and maucherite in the ore nests have been noted.

7) In ore nests containing an appreciable proportion of maucherite, the breithauptite is often finer-grained than in those consisting mainly of breithauptite. Often the breithauptite has apparently recrystallized into a finer-grained granular aggregate. Occasionally the optical orientation of adjoining grains in the recrystallized aggregates show only slight differences; they form "groups of individuals so closely bound together in their slightly scattered (optical) orientation that they are 
known as super-individuals" (KNoPF and Ingerson, 1938, p. 171) (e. g., figs. 9 and 10; Plate II, fig. 2; Plate III, fig. 1). The maucherite crystals associated with the recrystallized breithauptite show no signs of deformation and recrystallization.

8) The inclusions in any one myrmekitic individual usually are of about the same size, but in different individuals the size of the inclusions is independent of the size of the myrmekitic crystal. Of two myrmekites of equal size the one may contain coarser inclusions than the other and it is sometimes noted that the fine-grained inclusions are proportionally less densely spaced than the coarser-grained ones, so that variations in the relative proportions of maucherite and breithauptite in the myrmekitic intergrowths is evident. Extreme variation in these proportions is shown by the side by side occurrence of maucherite-breithauptite and breithauptite-maucherite myrmekites (Plate III, figs. 3 and 4). The latter-mentioned myrmekites are rather rare; they consist of breithauptite enclosing drops, streak-like and hook-shaped inclusions of maucherite. The maucherite inclusions within each breithauptite grain show uniform extinction. However, forms which may be regarded as intermediate between the two types of myrmekites are extremely rare; perhaps only an occasionally observed skeletal growth of columnar or tabular maucherite in breithauptite may be regarded as such (Plate III, fig. 4).

9) Possibly related to the breithauptite-maucherite myrmekites are some rather infrequent bladed intergrowths of breithauptite and maucherite (Plate III, fig. 1). They consist of blade-shaped inclusions of maucherite orientated parallel to the $(10 \overline{1} 0)$ or $(11 \overline{2} 0)$ directions in breithauptite and appearing in sections as spindles in one, two, or three directions. The blades often touch each other but do not intersect. They tend to occur in the centre of the host crystal. All blades within one crystal have a uniform optical orientation regardless of the directions of the blades.

The observations described under 1, 2, 4 and 7 indicate that at least a part of the maucherite is formed later than the breithauptite and has replaced areas of the latter mineral. Therefore, a eutectic, eutectoid, or exsolution origin of the myrmekites is not very probable; moreover, the observations mentioned in paragraphs 6 and 8 do not favour such an origin (for various other ways in which myrmekitic intergrowths may originate see RAмDонR 1945, 1960).

If the myrmekites have developed by replacement of breithauptite, this replacement is to be regarded as a maucherite crystalloblastesis. The maucherite has developed as poikiloblasts, sometimes showing a tendency to idiomorphism, within the areas of breithauptite. The observations mentioned under 3,4 and 5 suggest that many of the inclusions in the myrmekites may be regarded as replacement relics, but frequently it seems also evident that the breithauptite inclusions have recrystallized and were reoriented during the growth of the poikiloblasts. Aggregates of maucherite-breithauptite myrmekites, showing uniform orientation of inclusions 
within single grains, cannot have originated by a paramorphic grain by grain replacement of an original breithauptite aggregate since the crystal forms and grain sizes in the myrmekitic and in the breithauptite aggregates are often conspicuously different. Nevertheless, a certain relation in the crystallographic orientations of the intergrown minerals may be suspected. Possibly the orientation of the maucherite poikiloblasts was, at the beginning of their growth, influenced by that of the breithauptite grain, at the expense of which it was developing. When the maucherite poikiloblasts enlarged beyond the space of the original breithauptite grain, the adjoining breithauptite grain would be less favourably oriented; remnants of the latter which became included in the maucherite would presumably tend to recrystallize, adapting their orientation to that of the maucherite. Furthermore, as has been noted earlier (p. 28) maucherite-breithauptite myrmekites developing in the outer mixed zones of maucherite and breithauptite in zoned ore aggregates have sometimes replaced areas of niccolite and skutterudite, which are free of breithauptite inclusions. In the latter cases the breithauptite inclusions in the myrmekite are obviously not replacement relics. Conceivably the growing maucherite crystals may have taken up the breithauptite substance from the outer zones of the zoned aggregates, and when they proceeded to replace the niccolite the included breithauptite migrated along with its host into the area formerly occupied by niccolite and skutterudite; the process presumably involved an intragranular rearrangement and recrystallization of the breithauptite inclusions in the growing maucherite crystals.

As stated above, at least a part of the maucherite has been formed by replacement of breithauptite. That another part of the mineral may have been formed earlier than or contemporaneously with the crystallization or recrystallization of the bulk of the breithauptite is suggested by the occurrence of small, subhedral or euhedral maucherite crystals entirely enclosed in breithauptite. In these instances a comparatively coarse-grained aggregate of breithauptite with smaller grains of contemporaneous maucherite presumably formed first; during the subsequent maucherite blastesis the maucherite grains enlarged at the expense of those of breithauptite, which may have partially recrystallized into a finer-grained, often heterogranular aggregate.

The breithauptite-maucherite myrmekites and bladed intergrowths described under 8 and 9 have presumably been formed under the same conditions as the maucherite-breithauptite myrmekites, or, they are also thought to be due to the replacement of breithauptite by maucherite.

\section{Bladed intergrowths of maucherite and löllingite.}

Löllingite is found mostly as oriented blades enclosed in maucherite (Plate II, fig. 4; Plate IV, fig. 1), and occasionally as a few small grains attached to maucherite crystals. Only a few löllingite inclusions are found in the maucherite rims of zoned aggregates but they are abundant in the maucherite of the myrmekites. The löllingite blades are from about $0.1 \mathrm{~mm}$ long to almost submicroscopic in size and maucherite grains sometimes appear seemingly without löllingite inclusions.

In sections the spindle-shaped löllingite inclusions occur in one, two or three directions, parallel to the $\{111\}$ directions of maucherite. 
Parallel blades are optically uniformly oriented, but blades in different directions show different orientations. Very rarely the blades intersect each other, showing constrictions at the intersection. They are frequently most numerous and larger along the borders of the maucherite crystals and adjacent to galena inclusions in the latter; they are sometimes restricted to one side of the maucherite crystal. At the borders of the maucherite grains the löllingite blades broaden slightly and sometimes protrude a little into the adjoining maucherite or breithauptite grains. However, more commonly the blades stop abruptly at the crystal boundaries without spreading out. The same usually happens at the boundaries of breithauptite inclusions in myrmekitic maucherite, but occasionally löllingite blades do traverse smaller breithauptite inclusions, and sometimes the branching and spreading out of löllingite blades around breithauptite inclusions clearly indicates the later formation of the löllingite blades relative to the breithauptite inclusions in the maucherite. Löllingite blades have also been observed in the maucherite inclusions in breithauptite-maucherite myrmekites.

The maucherite-löllingite intergrowths are not likely to be of replacement origin, since almost no löllingite occurs outside the intergrowths and as löllingite blades are found in isolated maucherite inclusions in breithauptite. True exsolution textures are not to be expected as an addition of As seems necessary to form the intergrowths and as solid solution between these crystallographically different minerals is not to be expected. However, it is conceivable that the maucherite has originally taken up a certain amount of $\mathrm{Fe}$ and probably $\mathrm{Co}$ in its lattice, which were later segregated in the form of lölingite, presumably under the influence of an excess of As or of high vapour pressures of As ("Zerfallstruktur", RAMDOHR 1960).

\section{Network or cell textures of breithauptite and löllingite.}

Very rarely löllingite occurs as extremely fine veinlets and stringers in partly recrystallized fine-grained breithauptite, mostly adjoining maucherite grains. These networks or cell textures of breithauptite and löllingite are very similar in appearance to the niccolite-maucherite networks described earlier. Sometimes the breithauptite-löllingite networks appear surrounded by a clean rim of breithauptite (Plate IV, figs. 2 and 3), which suggests that (re)crystallization of the latter mineral has outlasted the formation of the breithauptite-löllingite networks, which therefore might be earlier than the löllingite formation in the maucherite.

The breithauptite-löllingite networks may possibly be linked with the maucherite blastesis, which is ascribed to the prevalence of high arsenic partial pressures favouring the formation of arsenides at the expense of breithauptite (see p. 46). These conditions may also have led to local segregations of löllingite during the breakdown or recrystallization of originally $\mathrm{Fe}$-, and probably Co-bearing breithauptite. 


\section{Breithauptite-maucherite-gudmundite relationships; bladed intergrowths of breithauptite and gudmundite.}

Gudmundite occurs as small subhedral crystals or rims around breithauptite or breithauptite-maucherite aggregates (Plate IV, fig. 2). The enclosed breithauptite usually appears recrystallized into an extremely fine-grained granular aggregate. Occasionally gudmundite grains are found interstitially between breithauptite and maucherite.

In one of the polished sections gudmundite occurs as fine, bladeor spindle-shaped inclusions, oriented parallel to the $(10 \overline{1} 0)$ or $(11 \overline{2} 0)$ directions in breithauptite (Plate IV, fig. 4). The blades occur in three directions in the central parts as well as along the borders of the breithauptite. Often the blades touch each other, forming three-bladed propeller-shaped stars, but intersection of blades has not been observed. Gudmundite inclusions are also found in the breithauptite inclusions in the maucherite-breithauptite myrmekites. In breithauptite-maucherite myrmekites the gudmundite blades sometimes spread out around the maucherite inclusions.

It seems most probable that the breithauptite-gudmundite intergrowths represent a "Zerfallstruktur" in the sense suggested for the maucherite-löllingite intergrowths. As pointed out by RAMDOHR (1960), these textures are genetically not sharply separable from certain exsolution and replacement textures. The network or cell textures of niccolite and maucherite and of breithauptite and löllingite are also a "Zerfallstruktur".

\section{The relations between galena and the other ore minerals.}

An older generation of galena occurs as a few small, rounded inclusions in breithauptite, and occasionally also in niccolite and maucherite (see also p. 31). A younger generation of galena has been observed in one section, where the mineral occurs as a rim around a corroded and rounded breithauptite-maucherite aggregate. 


\section{DISCUSSION AND CONCLUSIONS}

The nickel minerals described in this paper occur in natrolitized naujaite adjacent to an acmite-arfvedsonite vein. The ore minerals therefore may be genetically associated either with the agpaitic rock naujaite or with the late acmite-arfvedsonite vein. For this reason the ore minerals of the agpaitic rocks and the ægirine-acmite veins associated with some other alkaline rock complexes will be considered first.

\section{On the occurrence of nickel, cobalt and arsenic in agpaitic rocks.}

Nickel and cobalt are very rare elements in the agpaitic rocks (Gerasimovsky, 1956, p. 497).

In the agpaitic rocks of the Lovozero alkaline complex of the Kola peninsula cobalt and nickel are very rare. Traces of cobalt have been detected in ægirine II, chalcedony-like natrolite, mangano-ilmenite, genthelvite, pyrrhotite, galena, molybdenite, sphalerite and löllingite (?) The average content of nickel at Lovozero is $0.0003 \%$. Nickel has, been detected in ægirine I and II, ramsayite, hackmanite, schizolite arfvedsonite, steenstrupine, biotite, pyrrhotite, ussingite, sphalerite and löllingite (?). The löllingite (?) contains $2 \% \mathrm{Co}$ and $0.1 \% \mathrm{Ni}$ (cf. Vlasov et al., 1959).

According to Vlasov et al. (op.cit.) arsenic is a major component of the löllingite (?) of Lovozero. Traces of this element have been detected in natrolite, hydrocerite, karnasurtite, hydrogoethite, psilomelane and jarosite. Arsenic has not been detected in the rocks.

Ore minerals are rare in the agpaitic rocks of the Khibina and Lovozero complexes of Kola. From Khibina molybdenite, galena, cuprite, sphalerite, pyrrhotite, covellite, chalcopyrite, pyrite and marcasite have been mentioned as rare constituents in pegmatitic and albititic veins (FERSMan, 1937), while appreciable amounts of pyrrhotite occur in the contact metamorphosed country rocks of that massif. 
From Lovozero molybdenite, galena, sphalerite, pyrrhotite, pyrite, marcasite and löllingite (?) have been reported as constituents of eudialyte lujavrites, pegmatites and ussingite veins (Vlasov et al., 1959). The löllingite occurs in an ussingite pegmatite on the southeast slope of mount Punkaruajf as platy crystals of size $1 \times 2 \times 0.3 \mathrm{~cm}$.

The relations noted in Khibina and Lovozero should be compared with the rare occurrence of ore minerals in Ilimaussaq (cf. p. 8). The paucity of ore minerals is apparently a characteristic feature of the agpaitic rocks.

Spectrographic analyses of some agpaitic rocks from Ilímaussaq and the minerals of the late veins of that massif have been undertaken by Mr. I. Sørensen. According to these examinations cobalt and nickel can hardly be detected in these rocks and minerals and only very weak traces have been observed so far. However, chemical extraction of large samples of steenstrupine-bearing lujavrite from Ilímaussaq have been carried out in the chemical laboratories of the Danish Atomic Energy Commission at Risø. Nickel is present in the solution extracted from the lujavrite (Mr. E. Sørensen, personal information).

It may then be concluded that very weak traces of cobalt and nickel are present in the agpaitic rocks of Kola and Ilímaussaq and that arsenic is extremely scarce in these complexes.

\section{On the occurrence of ore minerals in late veins associated with alkaline rocks.}

Pegmatites and hydrothermal veins containing ægirine-acmite, often of fibrous habit, have been described from a number of alkaline complexes. They occur as fracture fillings in the alkaline rocks and in shear zones in the country rocks. The fenites around many alkaline complexes are often rich in acicular ægirine. It is therefore well established that fibrous or acicular æogirine may be formed from pneumatolytic and hydrothermal fluids expelled during the crystallization of alkaline magmas.

In the agpaitic rocks of Khibina and Lovozero three generations of ægirine have been established; ægirine I is magmatic, ægirine II epimagmatic, and ægirine III of hydrothermal origin (ef. Fersman, 1937 and VLasov et al., 1959). The amount of vanadium present in the ægirines of these rocks decreases from the first to the third generation (Shcherbina, 1960). In this connection it should be mentioned that the ægirine and acmite of the late veins in Ilimaussaq are practi- 
cally free of vanadium. They may thus be compared with the hydrothermal ægirine III of Kola.

Egirine III in Kola is associated with spreustein, natrolite, analcime, neptunite and more rarely with pyrite, pyrrhotite, galena, sphalerite, marcasite and chalcopyrite (Chirvinskr, 1939). The veins containing ægirine III are considered to be of very late formation in these alkaline complexes (RAmsay and HACKMAN, 1894).

In and around a number of alkaline complexes in the United States of America are veins containing fibrous ægirine, zeolites, sulphides and a great number of other minerals. Examples are: the Highwood Mountains, Montana (Larsen et al., 1941), the Bearpaw Mountains, Montana (Pecora, 1942), Libby, Montana (Larsen and Hunt, 1913; Goranson, 1927; and Larsen and Pardee, 1929) and Iron Hill, Gunnison County, California (LARSEN, 1941). In these occurrences ægirine is generally an early precipitate, while the zeolites and sulphides are late precipitates. The following ore minerals have been mentioned from these occurrences: galena, pyrite, chalcopyrite and sphalerite.

These few examples indicate that late hydrothermal veins associated with alkaline complexes may contain ægirine, zeolites and ore minerals.

\section{On the origin of the acmite-arfvedsonite veins}

\section{in Ilímaussaq.}

As described by Sørensen (1962) and as stated on p. 7 the acmitearfvedsonite veins occur only along fractures in the naujaite. Lujavrite veins and acmite-arfvedsonite veins may be contiguous in these fractures. The black lujavrites often contain inclusions of acmite-rich rocks but it is still uncertain whether or not these inclusions have been derived from enclosed and partly assimilated acmite-arfvedsonite veins. Displacements may have taken place along the acmite-arfvedsonite-bearing fractures. It has therefore been concluded that the acmite-arfvedsonite veins are contemporaneus with or slightly earlier than the emplacement of the black lujavrite. The veins were then formed in shear zones in the naujaite developed during the intrusion of the lujavrite. The acmite of these zones represents the crushed mafic minerals of the naujaite, the remaining naujaite minerals along the shear zones having been removed by leaching processes. At a later stage rest fluids expelled from the lujavrite percolated the fractures and the coarse-grained patches and the natrolitized border zones of the veins were formed. The late fluids were enriched in elements such as $\mathrm{Th}$, rare earths, $\mathrm{Nb}$, Li, Mn, P, Zn, Be and S. A part of some of these elements, especially Th, 
rare earths, $\mathrm{Nb}$ and $\mathrm{Mn}$, may have been derived by leaching from the naujaite adjacent to the fractures through which the fluids percolated.

The acmite-arfvedsonite veins are thus closely related to the formation of the lujavrite and have crystallized at temperatures and pressures ranging from those at which the lujavrite was formed to somewhat lower temperatures and pressures.

The order of crystallization of the lujavrite minerals is: 1. nepheline, 2. microcline, albite and some eudialyte, 3. eudialyte, 4. arfvedsonite and in some cases steenstrupine, 5. analcime. The feldspars are apparently a very pure maximum microcline and a pure low albite which appear to have been formed in mutual equilibrium as primary precipitates from the lujavrite magma. The available information indicates that this association has been formed at a rather low temperature, perhaps of the order of $400^{\circ} \mathrm{C}$. (cf. Sørensen, 1962). A low temperature of crystallization is also indicated by the fact that sodalite partly replaces the nepheline and that the albite (and sometimes also the nepheline and microcline) may be partially or entirely replaced by analcime. The sodalite and analcime in cases appear to be late primary magmatic minerals, but a part of the analcime is undoubtedly of deuteric origin.

The fact that the eudialyte of some lujavrites has been substituted by steenstrupine and that steenstrupine, and not eudialyte, occurs in the late veins should be compared with the experimental data of CHRISTOPHe-Michel LÉvy (1961) according to which eudialyte is unstable at temperatures below $440^{\circ} \mathrm{C}$.

The agpaitic rocks of Ilímaussaq are overlain by volcanic rocks which, according to Ussing (1912, p. 306), belong to the same period of igneous activity as the agpaites. This means that the depth of crystallization of the agpaitic rocks was of the order of a few kilometres giving a load pressure of up to a few thousand atmospheres.

From these data it is concluded that the formation of the acmitearfvedsonite veins commenced at temperatures of the order of about $400^{\circ} \mathrm{C}$ and at a comparatively high total pressure. The analcime-natrolite-rich patches of the veins were formed at lower temperatures and pressures.

The late fluids expelled from the crystallizing lujavrite magma have very probably been rather dense liquids at the indicated temperatures and pressures. As the pressure was released, a vapour phase may have been separated. The chemical environment suggests that the fluids were water-rich and alkaline (cf. FrFE et al., 1958). 


\section{Possible interpretations of the ore textures.}

The textural relationships of the ore minerals as described in the preceding chapter suggest the following order of formation of the minerals and their characteristic textures:

1. galena, skutterudite;

2. niccolite;

3. recrystallization of niccolite (and probably also skutterudite), niccolitemaucherite networks or cell textures with surrounding thin maucherite zones,

radial and concentric crack-fillings of columnar breithauptite around niccolitemaucherite intergrowths,

skutterudite-breithauptite and niccolite-breithauptite myrmekites;

4. coarsely granular breithauptite zones (in zoned ore nests) and aggregates, sometimes intermingled with some small maucherite idioblasts and maucheritebreithauptite myrmekites,

niccolite reaction zones in skutterudite along the boundaries with early-formed maucherite-breithauptite myrmekites;

5. maucherite blastesis involving the formation of the bulk of the maucheritebreithauptite myrmekites, the breithauptite-maucherite myrmekites and the breithauptite-maucherite bladed intergrowths;

6. breithauptite-löllingite networks or cell textures;

7. maucherite-löllingite bladed intergrowths;

8. breithauptite-gudmundite bladed intergrowths and gudmundite rims, rims of late galena.

The above-mentioned sequence and its overlapping relations are also represented in fig. 13. All minerals, with the exception of the minor amounts of galena, participate in the formation of one or more kinds of diablastic intergrowths (myrmekitic and bladed intergrowths, network or cell textures). Almost all of the maucherite, löllingite and gudmundite, and approximately $50 \%$ of the niccolite, breithauptite and skutterudite, occur as components of such intergrowths. In the following an attempt is made to interprete the above-mentioned textures in terms of controlling factors and to infer from this information the general conditions under which the ore minerals have been formed.

The niccolite-maucherite networks or cell textures appear as the first-formed characteristic intergrowths. A comparison with artificially produced textures described by Hawley and Hewit (1948 a and b) suggests that these intergrowths may be due to the partial dissociation of niccolite into maucherite and arsenic vapour. This suggestion finds support in the occurrence around the niccolite-maucherite intergrowths of radially and concentrically arranged breithauptite crack-fillings with columnar textures, which observation is consistent with the idea that maucherite formation, roughly coinciding with the introduction of breithauptite, was accompanied by the release of a vapour phase tending 


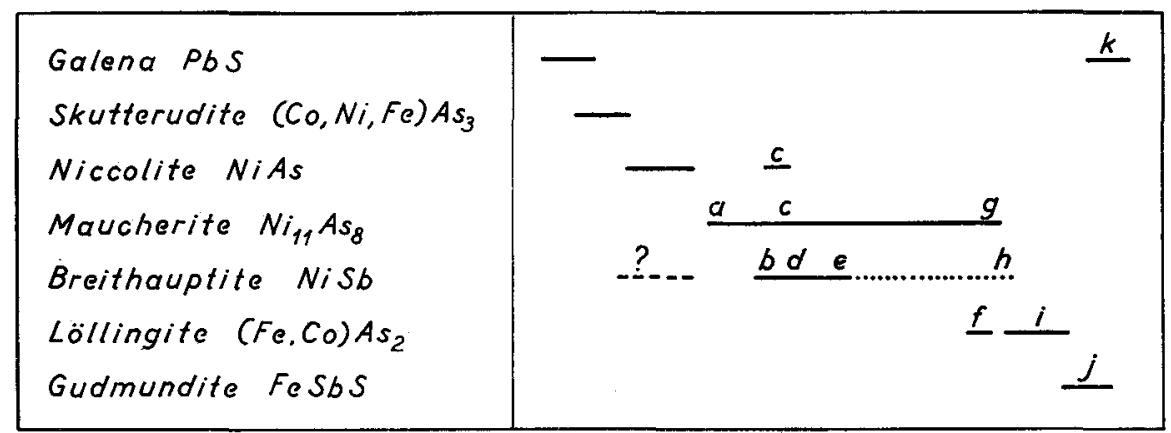

Fig. 13. Diagrammatic representation of the mineralogical and textural sequence of Ni-arsenides and associated ore minerals in a naujaite of the Ilimaussaq complex, South Greenland.

a. Beginning of partial dissociation of niccolite yielding maucherite and As-vapour. a-c. Niccolite-maucherite networks and zonal textures; recrystallization of niccolite and probably also of some skutterudite (not indicated in the figure). b-d. Crackfillings of columnar breithauptite; skutterudite-breithauptite and niccolite-breithauptite myrmekites; cementation of cracks and other openings with breithauptite and possibly other minerals. c. Niccolite reaction zones along skutterudite-maucherite boundaries; some fine-grained maucherite idioblasts and beginning of formation of maucherite-breithauptite myrmekites. d-e. Coarsely granular breithauptite aggregates. c-g. Maucherite-breithauptite myrmekites and breithauptite-maucherite myrmekites and bladed intergrowths. e-h. Local recrystallizations of breithauptite into finer-grained aggregates inside the maucherite-breithauptite myrmekites and around breithauptite-löllingite intergrowths. f. Segregation of löllingite from breithauptite, breithauptite-löllingite network and cell textures. i. Segregation of löllingite from maucherite, maucherite-löllingite bladed intergrowths. j. Segregation of g'udmundite from breithauptite, breithauptite-gudmundite bladed intergrowths and gudmundite rims. k. Rims of late galena.

to increase the volume of the reacting system in the ore nests (radial expansion cracks), whilst the volume of the solid phases decreased or remained constant (concentric cracks).

According to HewitT (1948, p. 415) partial dissociation of niccolite occurs around $450^{\circ} \mathrm{C}$, when NiAs is heated in sealed tubes. YUND (1959, pp. 148-150), reporting on the $\mathrm{Ni}-\mathrm{As}$ system, has made no mention of the dissociation of niccolite, but has confirmed earlier records of the incongruent melting of maucherite into niccolite plus liquid at $829^{\circ} \mathrm{C}$. These data suggest that temperatures between roughly speaking $450^{\circ}$ and $800^{\circ} \mathrm{C}$ have been reached during the formation of the ore minerals. However, a consideration of the mineral paragenesis in the associated zeolite-bearing acmite-arfvedsonite vein does not indicate such high temperatures. The possibility that the dissociation of niccolite in the rocks considered might have occurred at lower temperatures than as suggested above may be conceived on the following grounds: 
i) The experiments by HAwLEy and HewitT were carried out over a limited time. It may be expected that with sufficient time available the partial dissociation of niccolite may be accomplished at lower temperatures when other conditions are favourable.

ii) In analogy with results obtained by Kullerud and Yoder (1958), according to which the temperature at which pyrite breaks down to pyrrhotite and sulphur is lowered by the presence of water, a similar lowering of the dissociation temperature of niccolite due to a water-rich environment may be suspected.

iii) It is possible that fracturing and the circulation of water-rich fluids capable of dissolving arsenic, may have caused a lowering of arsenic vapour pressures, which would accelerate the breakdown of niccolite into maucherite (HAWLEY and HEWITT's experiments refer to a closed system).

Experiments by Vigouroux (1908) and Holmes (1947, p. 318) suggest that in an open system the As-content of Ni-arsenides decreases with increasing temperatures, so that the skutterudite-niccolite-maucherite sequence, as shown, e.g., by the niccolite reaction zones along the skutterudite-maucherite boundaries, may well be explained by a formation under conditions of increasing temperature. However, the effect of a variation in pressure should also be considered since a decrease in total pressure most probably will favour the formation of the most As-poor minerals.

Roseвоом (1959) has indicated that at lower temperatures in the Co-Ni-As system the pair niccolite-skutterudite seems to be the stable one relative to the pair safflorite-rammelsbergite. The lack of the latter pair in the present paragenesis of ore minerals may indicate that the temperatures at which this pair is stable were not attained before and during the formation of niccolite and skutterudite.

The complete preservation of the many intricate intergrowths of the ore minerals indicate that they have not been subjected to modifying influences after the formation of these textures. As mentioned above, the formation of the acmite-arfvedsonite vein commenced at temperatures of the order of $400^{\circ} \mathrm{C}$ and at rather high total pressures. The subsequent precipitation of analcime, natrolite, steenstrupine, etc. took place at lower temperatures and pressures. Two different ways of ore formation may then be possible:

i) The ore minerals were present as primary constituents of the naujaite. These ore minerals became modified by pneumatolytic-hydrothermal processes which accompanied the emplacement of the lujavrite. 
ii) The ore minerals were deposited in fractures in the naujaite by late fluids expelled from the crystallizing lujavrite magma. As discussed by Sørensen (1962) several stages of expulsion of fluid phases may have occurred. Following FERsman it may then be suggested that the phases expelled at the highest temperatures and pressures were enriched in the most volatile components of the magma such as, for instance, arsenic and antimony (cf. also Lovering, 1961). It is therefore not unreasonable to assume that there has been an early precipitation of nickel arsenides in a fracture in the naujaite. The later phases of fluids expelled from the lujavrite deposited the steenstrupine, analcime, natrolite, etc. in the fractures. During this process the firstformed ore minerals were modified. According to the experimental data available this may have taken place at not very low temperatures, i. e. earlier than the final crystallization of natrolite.

In the case that the ore minerals are assumed to have been present as original constituents of the naujaite, the early paragenesis presumably consisted of galena, skutterudite, niccolite and breithauptite, while other minerals such as gersdorffite may also have been present (HAwLEY, Stanton and Smith, 1961, have described niccolite-maucherite intergrowths resulting from the breakdown of gersdorffite). Subsequent pneumatolytic-hydrothermal activity connected with the intrusion of the lujavrite caused the partial dissociation of higher arsenides into lower arsenides and arsenic vapour. Skutterudite and niccolite apparently recrystallized in situ; the niccolite yielded some maucherite, which is partially held in the niccolite-maucherite network intergrowths and partially segregated as rims around these intergrowths, while the skutterudite was partially replaced by niccolite. At approximately the same stage breithauptite began to recrystallize and the mineral was redeposited as columnar aggregates in the cracks formed as a consequence of the volume changes attending the partial dissociation of niccolite. The latter crack-fillings, as well as the formation of some skutteruditebreithauptite myrmekitic intergrowths as a result of replacement by breithauptite, indicate that, unlike the arsenides, which recrystallized in situ, the breithauptite was at least partially remobilized during its recrystallization.

If, on the other hand, it is assumed that the ore minerals have crystallized from the late fluids expelled from the lujavrite magma, an overlapping subsequent deposition of galena, skutterudite and niccolite may be conceived during the first stages of a crystallization at rather high temperatures and pressures. The partial dissociation of 
the early-formed higher arsenides took place as soon as the appropriate temperatures and pressures were reached. The crystallization of breithauptite commenced at about this time.

Both of the possibilities considered above allow for the assumption that after the formation of skutterudite and niccolite and their partial breakdown and recrystallization in situ, the breithauptite, being still in the process of crystallization or recrystallization, behaved as a relatively more mobile (soluble) substance than the arsenides. A removal of parts of the antimony from the system at this stage is consistent with the preponderance of new arsenides over antimonide during the subsequent development.

It is suggested that after the cementation of the cracks with breithauptite and possibly other minerals (silicates), further (re)crystallization in the ore nests took place in a partly isolated system, permitting only very slow escape of volatiles. It is thought that under these circumstances the liberation of arsenic vapour, the partial removal of antimony and the (re)crystallization of breithauptite may cause a significant increase in the partial pressure of arsenic, so that with temperatures beginning to fall, the partial pressure of arsenic became in excess of that required for equilibrium conditions. As a consequence of this, arsenic tended to enter into the solid phases, accelerating the formation of maucherite at the expense of breithauptite. The formation of some maucherite idioblasts had presumably already been initiated contemporaneously with the (re)crystallization of breithauptite. The development of niccolite reaction zones at the expense of skutterudite along boundaries of the latter mineral with some maucherite-breithauptite myrmekites may indicate that the initially high temperatures still prevailed during the first stages of maucherite blastesis. However, the bulk of the abundant maucherite-breithauptite myrmekites, as well as the breithauptite-maucherite myrmekites and bladed intergrowths, apparently developed by replacement of breithauptite at a relatively late stage, presumably when temperatures had decreased appreciably. It is believed that the same critical conditions of excess arsenic pressures, persisting during further cooling, also caused the segregation of iron in the form of the diarsenide löllingite from the breithauptite (breithauptite-löllingite networks or cell textures) and from the maucherite (maucherite-löllingite bladed intergrowths).

During the modifications of the earlier formed minerals, a large proportion of the galena and possibly other sulphides were presumably dissolved and removed, so that galena is now found only as a few rounded, relic inclusions, mostly in (re)crystallized breithauptite. How- 
ever, a part of the dissolved galena was apparently redeposited at a late stage of cooling as a late generation of galena, whilst the late formaation of breithauptite-gudmundite bladed intergrowths and gudmundite rims may also be interpreted as a manifestation of the increasing sulphur concentrations in the residual phases.

The inferences made from a consideration of the characteristic ore textures may be briefly summarized as follows:

i) The present paragenesis of ore minerals and the ore textures are the result of a modification of an early-formed ore mineral assemblage.

ii) Changes in the partial vapour pressures of $\mathrm{As}, \mathrm{Sb}, \mathrm{S}$ and possibly other components were important factors controlling the mineralogical modifications at elevated temperatures as well as during the subsequent cooling.

iii) Fracturing of the rocks, later recementation of cracks, the circulation of hydrothermal fluids having differential dissolving powers for $\mathrm{As}$ and $\mathrm{Sb}$ and other elements, may be suggested as possible causes for the occurrence of changes in partial vapour pressures of the different elements.

iv) The ore minerals were formed earlier than the low temperature minerals of the acmite-arfvedsonite vein.

\section{On the origin of the ore minerals.}

The ore minerals described in the present paper occur in the border zone between naujaite and a late acmite-arfvedsonite vein which cuts the naujaite. The close association of the ore minerals with natrolite and small ægirine prisms, which occur in this border zone, suggests a relation between the ore minerals and the formation of the late vein. Textural evidence discussed in the preceding section indicates that the observed assemblage of ore minerals has been formed by recrystallization, partial mobilization and further modification of an earlier formed assemblage of ore minerals, which probably comprised galena, skutterudite, niccolite, breithauptite and possibly other minerals. A combined consideration of the geologic, petrologic and ore microscopic observations allow the following suggestions regarding the origin of the ore minerals:

i) The original assemblage of ore minerals crystallized as primary magmatic constituents of the naujaite. Later hydrothermal and pneumatolytic (?) action occurring in connection with the formation of the lujavrite and its accompanying late veins, caused modifications of the original ore minerals and their textures. Such an origin of the ore mine- 
rals is supported by the local occurrence of minerals such as pyrrhotite, stannite and polybasite in the naujaite. These minerals are not alien to parageneses of $\mathrm{Ni}-\mathrm{Co}$-Fe-arsenides. However, it is not yet known whether the pyrrhotite, etc. are primary minerals in the naujaite or of later origin. If these ore minerals are primary they have not been subjected to late modifications of the type seen in the nickel-arsenides at Igdlúnguaq. For example, the stannite found in the naujaite shows a finely developed lamellar twinning parallel to (001) and (100). According to Ramdofir (1960, p. 510-512) this cross-hatched microcline-like twinning in stannite is formed by the conversion of a high-temperature cubic form of stannite into its normal low-temperature form. Although the experimentally determined conversion temperature of $600^{\circ} \mathrm{C}$ is to be considered as improbably high (RAmpoHr, 1960, p. 512), it is obvious that the mineral must have crystallized at appreciably elevated temperatures, approaching those of magmatic conditions, and that the preservation of the conversion lamellae indicates the absence of further modification subsequent to the gradual cooling. Thus it seems that if the stannite is a primary magmatic mineral no marked temperature fluctuations occurred during the post-magmatic cooling stages of the naujaite. The modifications in the nickel-arsenides must then be ascribed to later actions in connection with the formation of the acmite vein.

ii) The ore minerals have been introduced into the naujaite as a result of pneumatolytic-hydrothermal action connected with the emplacement of the lujavrite. Hitherto, nickel-arsenides have not been found in the lujavrites of the complex, but, as stated on p. 39, the lujavrite is certainly nickel-bearing.

iii) Since it is known that nickel and cobalt are present in small traces in some of the silicate minerals of the naujaite, the possibility that the nickel, cobalt and iron of the ore minerals have been derived from these sources should also be considered. It is conceivable that these trace elements may have been leached out of the naujaite minerals adjacent to the fractures through which the late fluids percolated. The latter fluids may have introduced the arsenic and antimony of the ore minerals.

In conclusion it may be stated that the ore microscopic observations are consistent with all the three above suggested interpretations. The many diablastic and symplectitic intergrowths seem to characterize the metasomatic alteration of earlier formed ore minerals. The field observations are best accounted for by a combination of hypotheses 2 and 3 , but as hypothesis 1 also falls within the possibilities, the authors prefer to postpone a final statement until a systematic study of the ore minerals in the rocks of Ilímaussaq has been made. 


\section{LIST OF REFERENCES}

Chirvinsky, P. N., 1939: Paleohydrogeology of Khibina Tundras (in Russian). Bull.Ac.Sc. S.S.S.R., sér. géol. 1939, 4, 23-43.

Cristophe-Michel Lévy, M., 1961: Reproduction artificielle de quelques minéraux riches en zirconium (zircon, eudialyte, catapléite, elpidite); comparison avec leurs conditions naturelles de formation. Bull.Soc.Fr.Min.Crist. 84, 265-269.

DANø, M. \& H. SøRENSEN, 1959: An examination of some rare minerals from the nepheline syenites of South West Greenland. Medd. om Gronland, 162,5, $35 \mathrm{pp}$.

Ferguson, J., (1964): Geology of the Ilimaussaq intrusion. Medd. om Grønland, $172,4,84 \mathrm{pp}$.

Fersman, A. E., 1937: Minerals of the Khibina and Lovozero tundras. English Edition. Ac. Sc. Press, Moscow, 1937, 152 pp.

FLıNK, G., 1898: Berättelse om en mineralogisk Resa i Syd-Grønland, Sommaren 1897. Medd. om Grønland 14, 221-262.

Fyfe, W. S., F. J. Turner \& J. Verhoogen, 1958: Metamorphic reactions and metamorphic facies. Mem. Geol. Soc. Am. 73, 259 pp.

Gerasimovsky,V. I., 1956: Geochemistry and mineralogy of nepheline syenite intrusions. Geochemistry 1956, no. 5, 494-510.

Goranson, R. W., 1927: Aegirite from Libby, Montana. Am. Min. 12, 37-39.

Hawley, J. E. \& D. F. Hewitt, 1948 a: Pseudo-eutectic and pseudo-exsolution intergrowths of nickel-arsenides due to heat effects. Econ. Geol. 43, 273-279.

- $1948 \mathrm{~b}$ : Pseudo-exsolution intergrowths due to peritectic reactions involving partial dissociation. Am. Min. 33, 198.

Hawley, J. E., R. L. Stanton \& A. Y. Sмith, 1961: Pseudo-eutectic intergrowths in arsenical ores from Sudbury. Can. Min. 6, 555-575.

Hewitr, D. F., 1948: A partial study of the NiAs - NiSb system. Econ. Geol. 43, 408-417.

Heyding, R. D. \& L. D. Calvert, 1957: Arsenides of the transition metals. II. The nickel-arsenides. Can. Journ. Chem. 35, 1205-1215.

Holmes, R. J., 1947: Higher mineral arsenides of cobalt, nickel and iron. Bull, Geol. Soc. Am. 58, 299-391.

Knopf, E. B. and E. Ingerson, 1938: Structural petrology. Mem. Geol. Soc. Am. 6, $270 \mathrm{pp}$.

Kullenud, G., 1953: The FeS-ZnS system. A geological thermometer. Norsk geol. Tidsskr. 32, 61-147.

Kullerud, G. \& H. S. Yoder, 1958: Sulfide-water systems. Ann. Rep. Director Geophys. Lab., Washington, 1957-1958, 234.

Larsen, E. S., 1941: Alkalic rocks of the Iron Hill, Gunnison County, Colorado. U.S. Geol. Surv. Prof. Paper, 197 A, 64 pp.

Larsen, E. S. \& W. F. Hunt, 1913: Two vanadiferous aegirites from Libby, Montana. Am. J. Sc. 4. th. ser. 36, 289-296. 
Larsen, E. S., C. S. Hurlbut et al., 1939 \& 1941 : Igneous rocks of the Highwood Mountains, Montana. Bull. Geol. Soc. Am. 50 \& 52, $1939 \& 1941$.

Larsen, E. S. \& J. T. PArdeE, 1929: The stock of alkaline rocks near Libby, Montana. Journ. Geol. 37, 97-112.

Lovering, T. S., 1961: Sulfide ores formed from sulfide-deficient solutions. Econ. Geol. 56, 68-99.

Peacock, M. A., 1940: On maucherite (nickel-speiss, placodine, temiskamite). Min. Mag. 25, 557-572.

- 1941: On the identification of minerals by means of X-rays. Royal Soc. Canada, Transac. 3. d. ser., sec. IV, 35, 105-113.

Pecora, W. T., 1942: Nepheline syenite pegmatites, Rocky Boy Stock. Bearpaw Mountains, Montana. Am. Min. 27, 397-424.

RamdoнR, P., 1945: Myrmekitische Verwachsungen von Erzen. Neues Jahrb. Min. Beil. Bd. 79 A, 161-191.

- 1960: Die Erzmineralien und ihre Verwachsungen. 3. Aufl. Akademie Verlag, Berlin.

Ramsay, W. \& V. Hackmann, 1894: Das Nephelinsyenitgebiet auf der Halbinsel Kola. I. Fennia, 11, 2, 225 pp.

Roseвоom, E. H. jr., 1959: Natural assemblages in the Co - Ni - Fe - As - system. Ann. Rep. Director Geophys. Lab., Washington, 1958-1959, 153-155.

Sederholm, J. J., 1897: Über eine Archaische Sedimentformation im Südwestlichen Finland. Bull. Comm. Géol. Finlande, 1, no. 6.

Shснетвina, V. V., 1960: Die Verteilungseigenarten einiger seltener Elemente in Mineralien einer gemeinsamen Paragenese. N. Jb. Min. Abh. 94, Festband RamD OHR, 1093-1100.

Short, M. N., 1948: Microscopic determination of the ore minerals. 2. nd. Ed. Bull. U.S. Geol. Surv, 914, 314 pp.

Sørensen, H., 1958: The Ilímaussaq batholith, a review and discussion. Medd. om Grønland, 162, 3, $48 \mathrm{pp}$.

- 1960: On the agpaitic rocks. XXI. Int. Geol. Congr. 1960, Part XIII, 319-327.

- 1962: On the occurrence of steenstrupine in the Ilímaussaq massif, Southwest Greenland. Medd. om Grønland 167, 1, $251 \mathrm{pp.}$

Ussing, N. V., 1912: Geology of the country around Julianehaab, Greenland. Medd. om Grønland, 38, $376 \mathrm{pp}$.

Uytenbogande, W., 1951: Tables for microscopic identification of ore minerals. Princeton Univ. Press, Princeton.

Vigouroux, E. M., 1908: Action du trichlorure d'arsenic sur le nickel et sur les arsenionickels. Ac. Sc. Paris, C. R. 147, 408-417.

Vlasof, K. A., M. V. Kuzmenko \& E. M. Eskova, 1959: The Lovozero alkaline massif (in Russian). The Ac. Sc. Moscow, 624 pp.

Yund, R. A., 1959: The Ni - As - S - system. Ann. Rep. Director Geophys. Lab., Washington, 1958-1959, 148-153.

- 1961: Phase relations in the system Ni-As. Econ. Geol. 56, 1273-1296. 


\section{PLATES}




\section{Plate I.}

Fig. 1. Aggregates of ore minerals consisting mainly of maucherite-breithauptite myrmekites and breithauptite. The ore minerals occur enclosed in natrolite and sodalite. (Black area). (1 nicol, $80 \mathrm{x}$ ).

Fig. 2. Network of very fine, intergranular maucherite veinlets and stringers in a finely granular niccolite aggregate. In this example the maucherite zone around the niccolite is surrounded by a breithauptite rim (appearing in the same shades of grey as niccolite), which do not show intergrowths with maucherite. The straight boundary between the niccolite-maucherite aggregate and the breithauptite rim in the lower part of the picture suggests that the granular texture of the niccolite is due to recrystallization of a formerly subhedral or euhedral niccolite crystal. (1 nicol, $430 \mathrm{x}$ ).

(Chr. Halkier phot.). 
Medp. om Gronl. Be. 172, Nr. 1. [Oex Iyg Soen and Henxing Sorensen] Plate I.

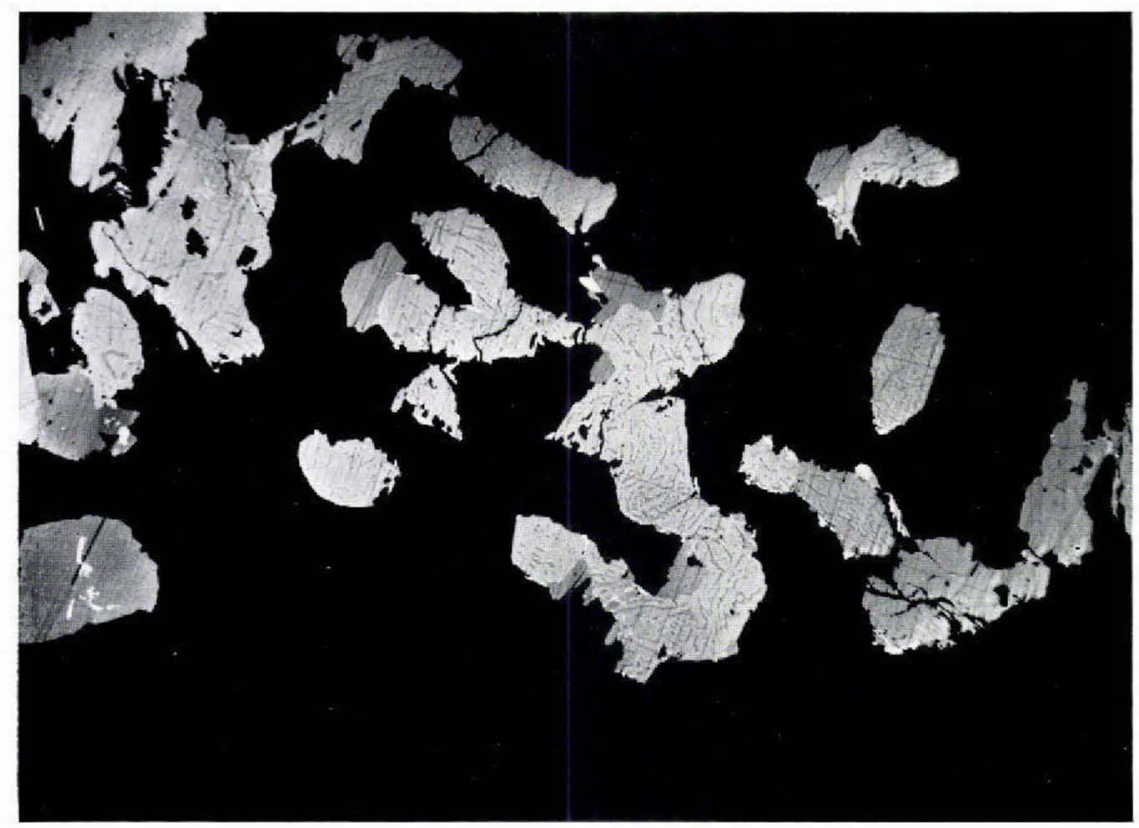

Fig. 1.

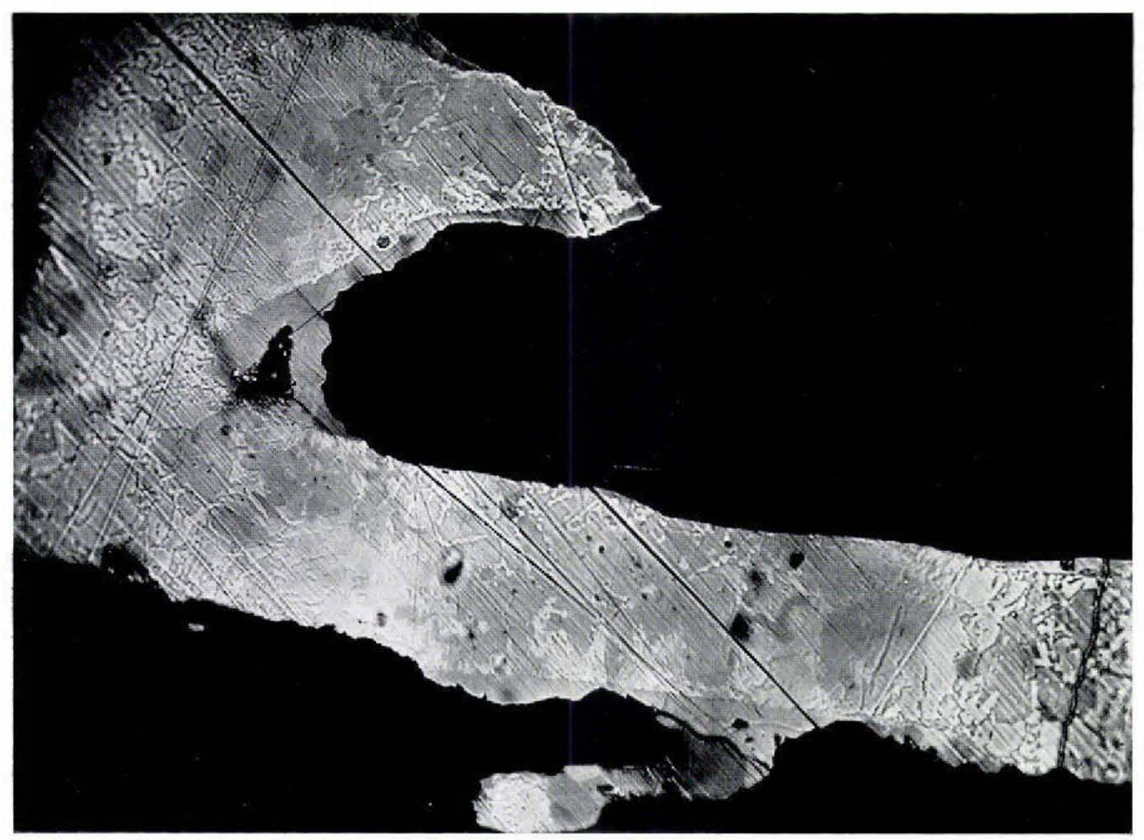

Fig. 2. 


\section{Plate II.}

Fig. 1. Rims and veinlets of breithauptite with columnar textures (ruled in fig. 7) developed around an aggregate consisting of niccolite and maucherite (stippled area in fig. 7). The latter aggregate consists mainly of granular, apparently recrystallized niccolite (appearring in the photograph in shades of light and dark grey to black), veined by very fine intergranular maucherite veinlets and surrounded by a narrow, irregular maucherite zone. The maucherite appears in an intermediate tint of grey, contrasting very poorly with the niccolite. However, the textural relations are visible in that part of the photograph marked with a cross in fig. 7; here the niccolite is almost white, while the maucherite veinlets appear darker grey. Note the typical outline of the niccolite-maucherite aggregate, strongly suggestive of the former existence of a euhedral niccolite crystal. (2 nicols, $240 \mathrm{x}$ ).

Fig. 2. Subhedral maucherite-breithauptite myrmekites. The maucherite grains $M_{1}$ and $M_{2}$ (see key on fig. 9) probably have a twin relationship. The breithauptite inclusions in $M_{1}$ have the same optical orientation as that of the adjoining breithauptite grain $B_{1}$, which appear dark and therefore cannot be distinguished in the photograph (compare fig. 9); those in $\mathbf{M}_{2}, \mathbf{M}_{3}$ and $\mathbf{M}_{4}$ have orientations which are obviously related to that of the breithauptite "superindividual" Bs. The latter consists of a group of breithauptite grains, the orientation of which varies so little that in the present case it may be suggested that they formerly formed a single homogeneous grain. The myrmekite $\mathbf{M}_{5}$ has few inclusions, which are not easily seen in the photograph owing to the unfavourable optical orientation of the grains. The black inclusions in the ore minerals are transparent gangue material. Note the straight boundaries and clean rims of the myrmekitic crystals, suggesting that no corrosion of maucherite by breithauptite has taken place. (2 nicols, $160 \mathrm{x}$ ).

Fig. 3. Rims and radial veinlets of breithauptite with columnar texture (ruled in fig. 8). The central part of the ore nests consists of fine-grained niccolite (stippled in fig. 8). An intermediate zone of maucherite is well developed, but it does not appear clearly on the photograph; the maucherite zone is shown in fig. 8 (crosses). (2 nicols, $160 \mathrm{x}$ ).

Fig. 4. The maucherite-breithauptite myrmekite in the central part of the figure tends to occur interstitially in a comparatively coarse-grained breithauptite aggregate (various shades of grey). The breithauptite inclusions in the myrmekite have the same optical orientation as the breithauptite grain just below the myrmekite. Löllingite blades (white) appear as parallel lamellae along two directions in the maucherite and concentrated along its borders. Small, dark grey to black spots in the upper right hand part of the picture are inclusions of galena, which occur as rounded drops when enclosed by breithauptite, but the rounded outlines of which appear to have been destroyed by corrosion when occurring in contact with maucherite or löllingite (as in this picture); these relations suggest the formation of the latter minerals to be later than that of the breithauptite. (1 nicol, $160 \mathrm{x}$ ).

(Chr. Halkier phot.). 


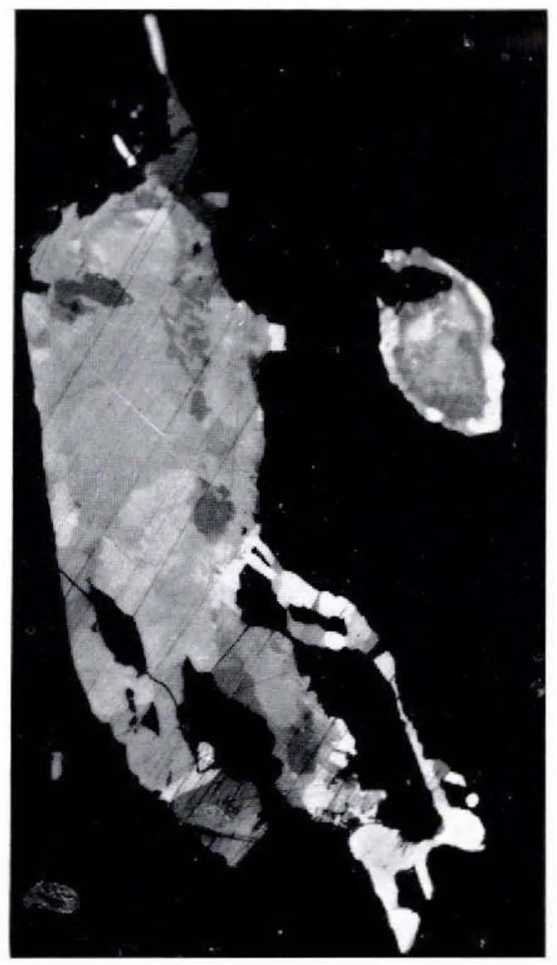

Fig. 1

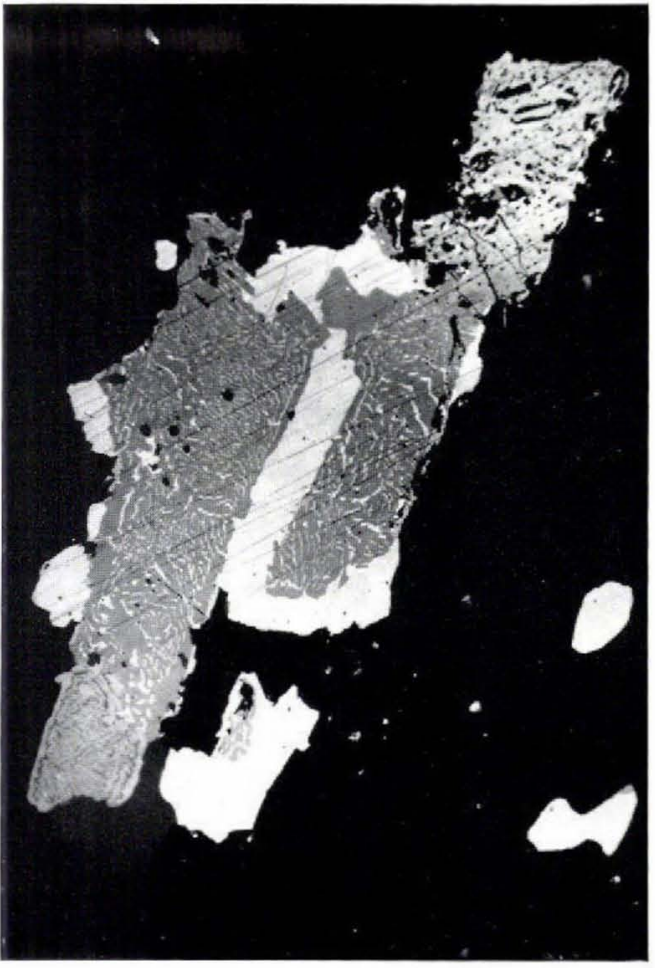

Fig. 2 .

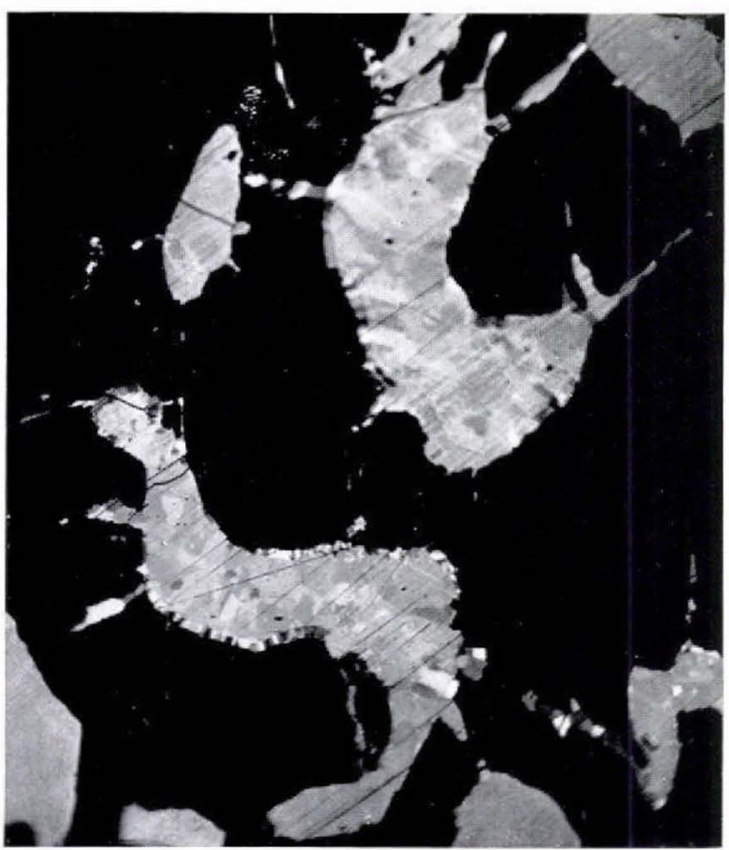

Fig. 3.

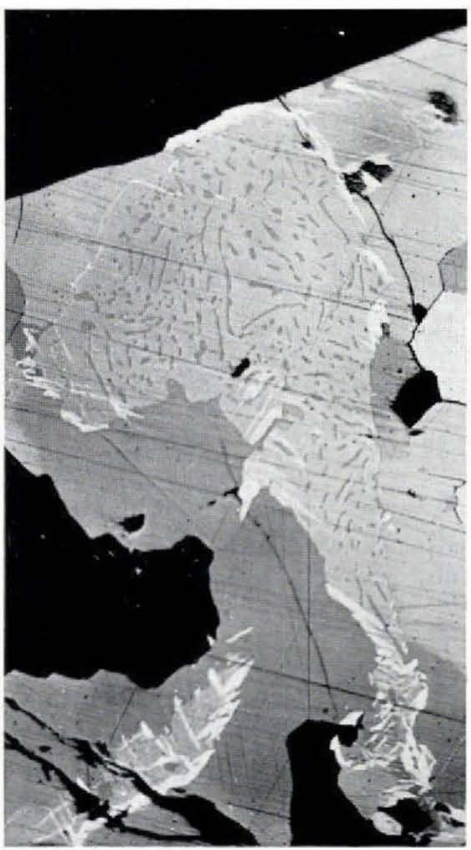

Fig. 4 . 


\section{Plate III.}

Fig. 1. Maucherite-breithauptite myrmekites and a bladed intergrowth of breithauptite and maucherite. In the photograph the breithauptite appears dark grey to black, the maucherite light grey to white. The maucherite blades (left of the centre of the photograph) occur enclosed within a breithauptite grain, the optical orientation of which differs so little from that of neighbouring breithauptite grains, that a "superindividual" is defined. The breithauptite inclusions within each of the maucherite-breithauptite myrmekites are generally uniformly oriented and an adjoining breithauptite grain showing the same or approximately the same orientation can usually be seen. Some of the myrmekites show two groups of optically and spatially related inclusions (see fig. 10; upper right hand corner). The oriented löllingite blades in maucherite are sometimes faintly visible in the photograph. In fig. 10 the different directions of the striation indicate different optical orientations of breithauptite grains. "Superindividuals" are uniformly striated. The direction of broken lines in the maucherite-breithauptite myrmekites indicates the optical orientation of the breithauptite inclusions in the myrmekite. A relation between the orientation of the inclusions and those of breithauptite grains is clearly indicated (see also figs. 11 and 12). (2 nicols, $160 \mathrm{x}$ ).

Fig. 2. Longitudinal and cross section of euhedral maucherite-breithauptite myrmekites. The cross section is presumably of a twinned crystal. Note that in one part of the twinned crystal the breithauptite inclusions appear as black spots on the picture, whereas in the other part the inclusions appear as light coloured bars, showing the same optical orientation as the surrounding breithauptite grain. Note also the clean borders of the myrmekites and, furthermore, the faintly visible löllingite blades occurring in three directions in the twinned maucherite crystal. ( 2 nicols, $160 \mathrm{x}$ ).

Fig. 3. Breithauptite-maucherite myrmekite (large grey coloured grain with white inclusions) and maucherite-breithauptite myrmekite (white grain with grey inclusions in upper left side of picture) occurring closely associated. (2 nicols, $160 \mathrm{x}$ ).

Fig. 4. The upper part of the picture shows a breithauptite-maucherite myrmekite, in which the maucherite inclusions have an optical orientation similar to that of the skeletal grains of maucherite shown about the central part of the figure (maucherite appears black to dark grey in the photograph, breithauptite is white to dark grey). The lower part of the figure shows an aggregate of maucherite-breithauptite myrmekites. ( 2 nicols, $80 \mathrm{x}$ ).

(Chr. HALKIER phot.). 


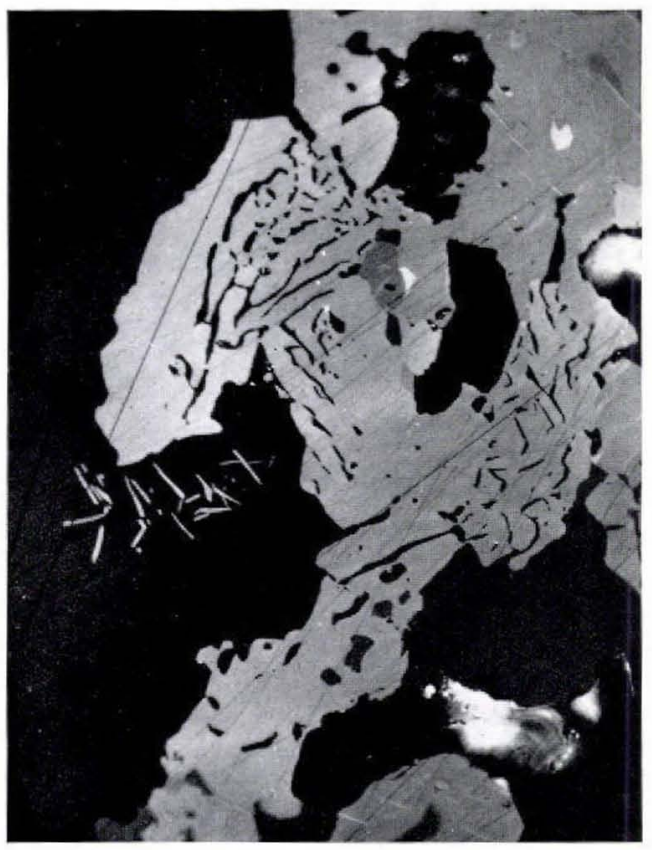

Fig. 1.

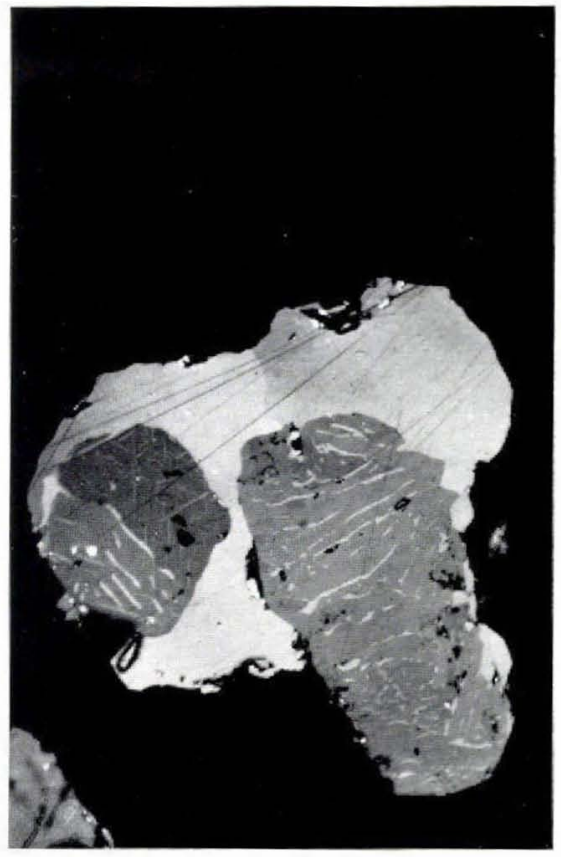

Fig. 2,

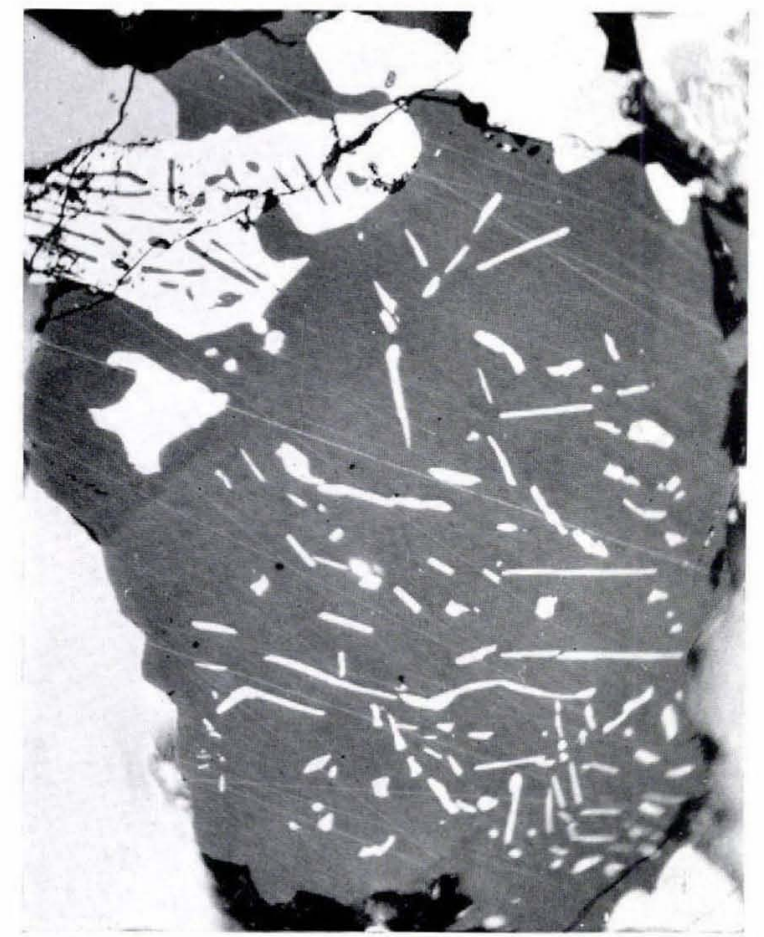

Fig. 3.

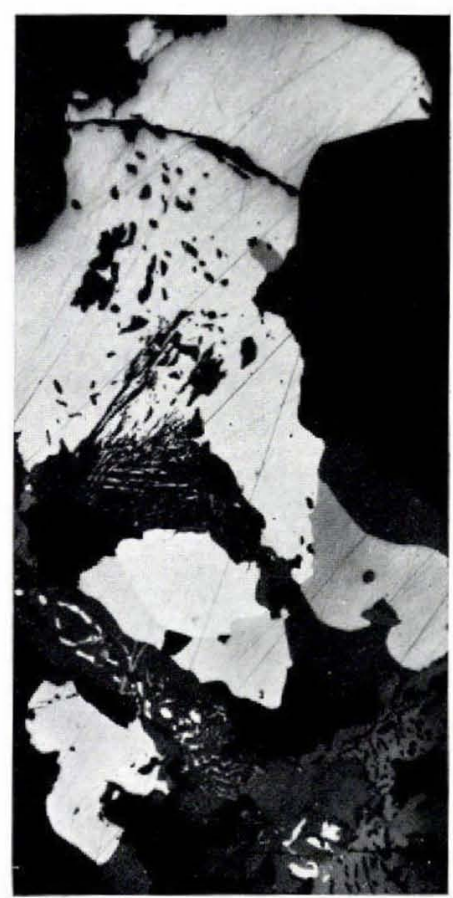

Fig. 4. 


\section{Plate IV.}

Fig. 1. An aggregate of maucherite-breithauptite myrmekites in which the maucherite contains abundant oriented blades of löllingite. The optical orientations of the breithauptite inclusions and the directions of the lobllingite blades change with the orientation of the maucherite host. Areas of granular breithauptite sometimes occur partly or completely enclosed in the myrmekitic aggregate. (2 nicols, $160 \mathrm{x})$.

Fig. 2. Gudmundite crystals (white) forming rims around very finely granular, presumably recrystallized breithauptite aggregates. Fine-grained interstitial löllingite occurs in the recrystallized breithauptite areas, where it forms a network or cell texture. (1 nicol, $160 \mathrm{x}$ ).

Fig. 3. Breithauptite-löllingite network or cell textures consisting of very finegrained breithauptite with intergranular löllingite. The networks are surrounded by a clean rim of coarser-grained breithauptite. Grains of maucherite-breithauptite myrmekites occur enclosed in or adjacent to the breithauptite-löllingite networks. The maucherite commonly contains löllingite blades. (1 nicol, $160 \mathrm{x}$ ).

Fig. 4. Bladed intergrowths of gudmundite (white) and breithauptite (light grey). Darker grey myrmekitic crystals (left-hand and lower part of photograph) are maucherite-breithauptite myrmekites. ( 1 nicol, $160 \mathrm{x}$ ).

(Chr. Halkier phot.). 
Medd, om Gronl. Bd. 172, Nr. 1. [Oex Ing Soen and Hennixg Sorexsex] Plate IV.

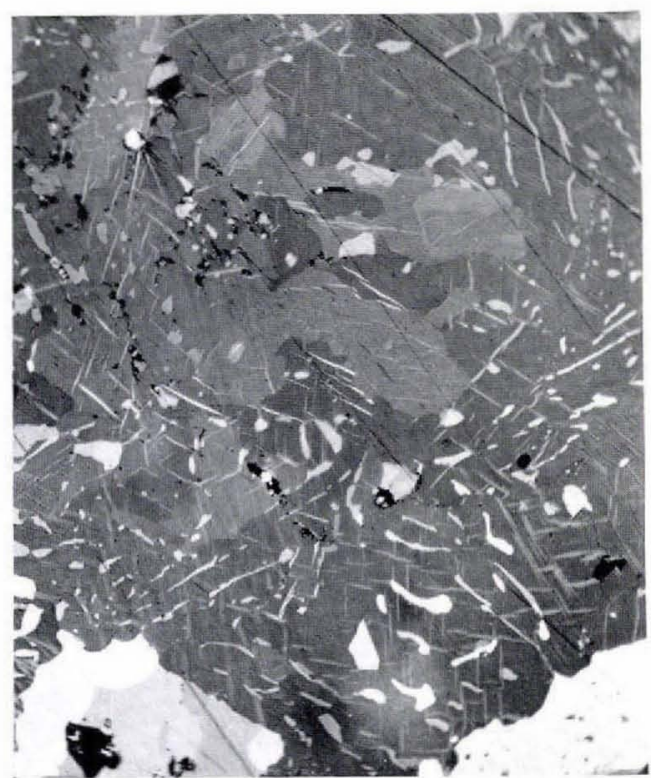

Fig. 1.

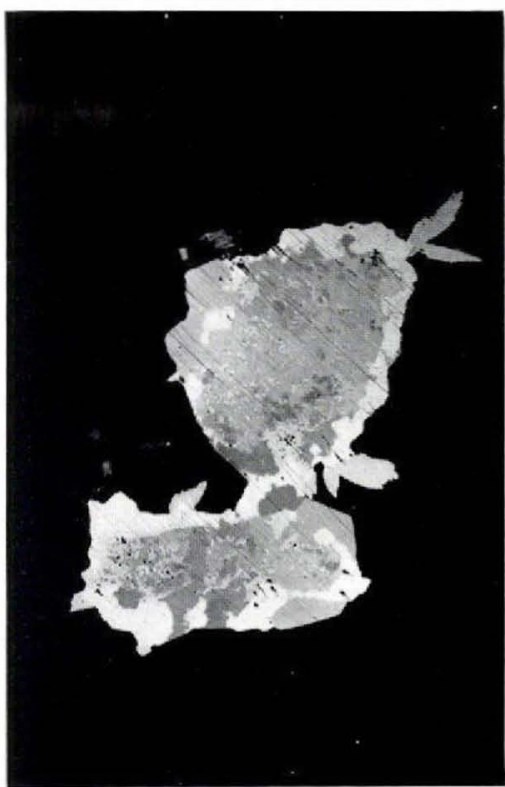

Fig. 2.

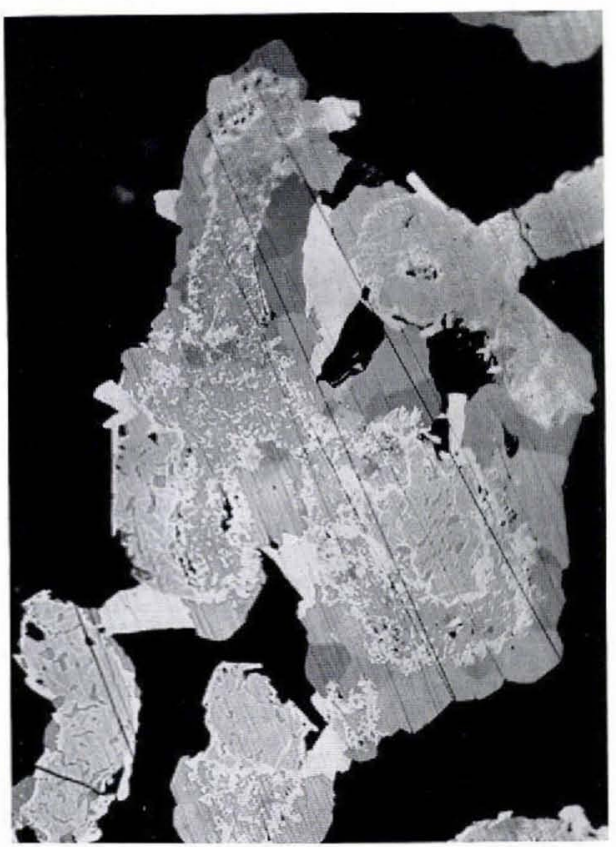

Fig. 3.

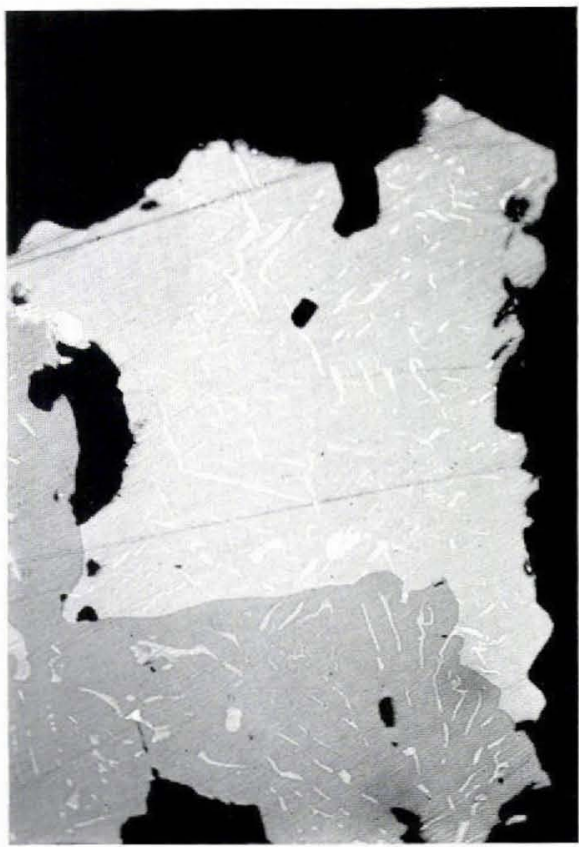

Fig. 1. 